\title{
Party Autonomy: Removing Obstacles to Legal Diversity in the European Market*
}

\author{
Afonso Patrão ${ }^{* *}$
}

\begin{abstract}
One of the main obstacles to the internal market is legal diversity: Member States often adopt different legal standards not only within public and economic law but also with regard to private law. The traditional approach of European Institutions (harmonising legislation among Member States) was soon complemented by the principle of mutual recognition; these two methodologies embodied the European strategy for minimising the problem. However, a third European tool is becoming obvious: to give private parties the ability to choose the applicable law. This new approach enhances regulatory competition among Member States and turns unessential the unification of national rules, which suits best the proportionality principle. Party autonomy as a means for overcoming the difficulties of legal diversity is not only a reality in European statutory law - which already brought the ability for choosing the applicable law to contracts, torts, divorce, inheritance, alimony, matrimonial property - but is also highlighted in ECJ's case-law, which declared legal diversity is not a barrier to the basic freedoms as long as parties may choose the applicable rules.
\end{abstract}

The article will focus on the grounds and advantages of this method to address the issue of legal diversity, advocating its use in areas where the traditional approach is ineffective or impossible (such as some rights in rem, within the scope of the freedom of movement of capital).

KEYWORDS: Party autonomy; Internal market; Conflict of laws; Legal diversity; free movement

\footnotetext{
* Date of Reception: 10 December 2018. Date of Acceptance: 28 January 2019.

** Assistant Professor, Faculdade de Direito da Universidade de Coimbra, 3030-489, Coimbra, apatrao@fd.uc.pt.
} 


\section{Legal diversity: a remaining obstacle to the internal market}

Since the beginning of European integration, legal diversity has been an obstacle to the internal market. Because each Member State has its own legal standards, an economic agent from one Member State must take into account different rules of the country of destination, in order to benefit from the basic freedoms. Legal diversity (both within private and public law) is, therefore, an important barrier to the purposes of the European Union.

Consider an example: if a Bank from Member State A wishes to benefit from the freedom to provide services and the freedom of movement of capital by loaning mortgage credit to a company of Member State B, the deal will defy important adversities due to legal discrepancy: the security right will be mandatorily ruled by the law of situation of the plot, ${ }^{1}$ which could be unknown to the creditor. Therefore, it will be necessary to hire legal counselling, increasing the costs of credit and, possibly, making it economically unworthy. In the European Commission's words, legal diversity is one of the "legal barriers (...) which prevent mortgage lenders from offering certain products in certain markets or opting for a given funding strategy".

\footnotetext{
${ }^{1}$ The lex rei sitae rule on property rights on immoveable property is unanimous in all Member States - Afonso Patrão, Autonomia Conflitual na Hipoteca e Reforço da Cooperação Internacional: Removendo Obstáculos ao Mercado Europeu de Garantias Imobiliárias (Lisboa: Livros Horizonte, 2017), 80.

${ }^{2}$ European Commission, White Paper on the Integration of EU Mortgage Credit Markets - COM(2007)807 Final (Brussels 2007), https://eur-lex.europa.eu/legal-content/EN/ TXT/?uri=celex\%3A52007DC0807, 4. On legal diversity on mortgage credit, cf. Alfonso Luis Calvo Caravaca and Javier Carrascosa González, Derecho Internacional Privado (Granada: Ed. Comares, 2011), 77: "En efecto, si la Ley aplicable a una situación jurídica es más severa o, simplemente, es diferente en los distintos Estados miembros, los particulares pueden sentirse 'desincentivados' a circular por la UE. La diversidad de Leyes aplicables a una misma situación privada internacional en los Estados miembros opera, en estos casos, como un auténtico obstáculo a las libertades de circulación de la UE”; Sergio Nasarre Aznar, “The Eurohypothec: a common mortgage for Europe”, The Conveyancer and the Property Lawyer (2005), 32: "The main problems are the differences between the laws on mortgages in the different European countries"; Elena Sánchez Jordán, "Garantías sobre bienes inmuebles: La Eurohipoteca", in Derecho Privado Europeo, ed. Sergio Cámara Lapuente (Madrid: Editorial Colex, 2003), 990-993: "De entre todas ellas, hay una que destaca sobre el resto: las grandes diferencias que existen, por una parte, en la regulación de los derechos reales de garantía sobre inmuebles - en concreto, de las hipotecas - que se contemplan en los distintos Estados miembros y, por otra, en los sistemas de publicidad registral"; Ulrich Drobnig, "The law governing credit security", in The Private Law Systems in the EU: Discrimination on Grounds of Nationality and the Need for a European Civil Code, ed. Parlamento Europeu - Directorate General for Research (Bruxelas: 2000), 57: "rooted in the strong traditions in the domain of land law and
} 
influenced by the close connection that exists between land law and the prevailing system of land registration, these provisions diverge very sharply"; Thomas Wachter, "La garantie de crédit transfrontalier sur les immeubles au sein de l'Union européenne - L'Eurohypothèque”, Notarius International 4, no. 4 (1999): 174 "le marché commun européen des sûretés n’a pas encore pu être réalisé en raison des différences des systèmes hypothécaires qui sont traditionnellement marqués par les droits nationaux", and "Die Eurohypothek - Grenzüberschreitende Kreditsicherung an Grundstücken im Europäischen Binnenmarkt”, Zeitschrift für Wirtschafts- und Bankrecht (WM - Wertpapier Mitteilungen) 53, no. 2 (1999): 49; Gary Watt, "The Eurohypothec and the English Mortgage", Maastricht Journal of European and Comparative Law 13, no. 2 (2006): 176 "This is attributable in large part to differences between national laws governing security over immovable assets"; London Economics, The Costs and Benefits of Integration of EU Mortgage Markets - Report for European Commission, DG-Internal Market and Services (London, 2005), 9: "lenders tend to be discouraged from lending across borders by the fact that they would be bound by the legal system of the borrowers' country"; Mónica Jardim, "A euro-hipoteca e os diversos sistemas registais europeus", Boletim da Faculdade de Direito da Universidade de Coimbra LXXXV (2009): 743; Luís Menezes Leitão, Garantias das Obrigações (Coimbra: Almedina, 2012), 49; Armindo Saraiva Matias, "Obrigações hipotecárias e titularização de créditos hipotecários", Boletim da Faculdade de Direito da Universidade de Coimbra LXXXV (2009): 623; Isabel Menéres Campos, "O direito português da hipoteca", Boletim da Faculdade de Direito da Universidade de Coimbra LXXXV: 725; Pedro Pires Fernandes, Da Euro-Hipoteca: Exposição da Proposta e Suas Características Principais. Dissertação de Mestrado apresentada à Faculdade de Direito da Universidade de Coimbra (Coimbra: policopied, 2008), 42; Agnieszka Drewics-Tulodzieca, "Foreword", in Basic Guidelines for a Eurohypothec - Outcome of the Eurohypothec Workshop November 2004/April 2005, ed. Agnieszka Drewics-Tulodzieca (Warsaw: Mortgage Credit Foundation, 2005), 3; Andreas Luckow, "Charts on business structures", in Basic Guidelines for a Eurohypothec - Outcome of the Eurohypothec Workshop November 2004/April 2005, ed. Agnieszka Drewics-Tulodzieca (Warsaw: Mortgage Credit Foundation, 2005), 25; Andrés Domínguez Luelmo, "Derechos de garantía sobre bienes muebles", in Derecho Privado Europeo, ed. Sergio Cámara Lapuente (Madrid: Editorial Colex, 2003), 967; Eveline Ramaekers, European Union Property Law - From Fragments to a System, (Cambridge - Antwerp: Intersentia, 2013), 5; Simon Low, Matthew Sebag-Montefiore, and Achim Dübel, Study on the Financial Integration of European Mortgage Markets, (London: Mercer Oliver Wyman - European Mortgage Federation, 2003), 54 and 81; Roy Goode, “The Cape Town Convention on International Interests in Mobile Equipment", in Towards a European Civil Code, ed. Arthur Hartkamp, et al. (Haia: Kluwer Law International, 2004), 757; Hendrik Ploeger and Bastiaan van Loenen, Response to the Green Paper on Mortgage Credit in the EU (Delft, 2005), http://ec.europa.eu/internal_market/finservices-retail/docs/home-loans/comments/priv-nl_ ploeger_vanloenen-en.pdf, 1; Bram Akkermans, "Property law and internal market", in The Future of European Property Law, ed. Sjef van Erp, Arthur Salomons, and Bram Akkermans (Munique: Sellier European Law Publishers, 2012), 223; Dominique Servais, Intégration des marchés financiers, in Commentaire J. Mégret (Bruxelas: Éditions de l'Université de Bruxelles - Institut d'Études Européennes, 2007), 364; Nina Scherber, Europäische Grundpfandrechte in der nationalen und internationalen Insolvenz im Rechtsvergleich (Frankfurt am Main: Peter Lang, 2004), 152; Claudio Segré, The Development of a European Capital Market (Bruxelas: Comissão Europeia, 1966), http:// aei.pitt.edu/31823/1/Dev_Eur_Cap_Mkt_1966.pdf, 177; Nuria Bouza Vidal, "Modalidades de unificación y armonización de legislaciones en la Comunidad Económica Europea”, in Tratado de Derecho Comunitario Europeo, ed. Eduardo García de Enterría, Julio González Campos, and 
Legal diversity is a barrier to the proper functioning of the internal market which European Institutions have been fighting: firstly, by harmonising and unifying the legal standards of each Member State; afterwards, by implementing mutual recognition, which could keep the existence of different legal rules without repressing free movement.

In this article, we plan to show there is a third tendency of the European Union in order to accomplish freedom of movement, despite legal diversity: allowing private parties to choose the applicable law (professio iuris) to several domains. The European Institutions are minimising the difficulties of the existence of different standards by granting citizens and companies the right to elect the legal system of their preference, thus promoting competition between Member States and reassuring stability and confidence to economic operators, notwithstanding the EU country where they act.

\section{Unification of laws and mutual recognition: the persistence of difficulties}

The traditional approach to the obstacles conceived by legal diversity was the unification or harmonisation of national laws, even in fields not directly connected to the internal market: the inequality of standards compels private parties to adjust to different rules and engenders uncertainty, justifying the competence of the European Union to promote the approximation of laws (arts. 114 to 118 TFEU). ${ }^{3}$

Santiago Muñoz Machado (Madrid: Editorial Civitas, 1986), 551; Andrés Rodríguez Benot and Alfonso Ybarra Bores, "La armonización del crédito hipotecario en la Unión Europea”, Revista Analuza de Derecho del Turismo 5 (2011): 122; Wulf-Henning Roth, "Secured credit and the internal market: The fundamental freedoms and the EU's mandate for legislation”, in The Future of Secured Credit in Europe, ed. Horst Eidenmüller and Eva-Maria Kieninger (Munique: De Gruyter Recht, 2008), 38; Oliva Rocío Diéguez, La Eurohipoteca: Luces y Sombras de la Pretendida Unificación en Materia Hipotecaria (Berkeley: eScholarship, 2009), http://escholarship.org/uc/item/2s48r5vn, 3; Alain Gourio, "Le nouveau cadre juridique juridique du crédit aux particuliers en Europe", Revue de Droit Bancaire et Financier 4, no. 2 (2003): 142; Eurohypothec Research Group, Response to the Green Paper on Mortgage Credit in the EU, (2005), http://ec.europa.eu/internal_market/finservices-retail/docs/home-loans/comments/priv-es_eurohypothec-es.pdf, 9.

${ }^{3}$ This difficulty was already stressed in 1972 by Isabel de Magalhães Collaço, "Os reflexos do movimento de integração económica no direito privado e no direito internacional privado", in Da Execução das Decisões Arbitrais e Judiciais em Direito Internacional: Noveno Congreso, Lisboa, 2-11 de Novembro de 1972 (Madrid: Secretaría General, 1972): "mostra a experiência que os movimentos de integração económica - pelo menos os que visam as formas mais avançadas de integração - se repercutem [...] na unificação ou harmonização de legislações em sectores com reflexo directo na actividade económico-privada no espaço integrado" (p. 7); “é fácil compreender que a criação do mercado comum [...] suscite a necessidade de uma unificação ou harmonização jurídica 
However, there are known difficulties to unification, which made utopic the idea that legal diversity would disappear only by this approach: the impossibility of entirely abolishing disparity, due to possible different interpretations of uniform rules and by reason of interaction of those rules with the remaining internal legal system; slowness, difficulty and costs of the unification process; renunciation to the power of Member States of adapting the rules to their national communities; eradication of regulatory competition between Member States, which engenders so many good outcomes. ${ }^{4}$

Therefore, when the European Court of Justice (ECJ) pronounced the principle of mutual recognition, European Institutions with law-making

muito largas, em ordem a garantir o funcionamento, sem distorções graves, das leis do mercado no espaço económico integrado" (p. 14). Also, Georges van Hecke, "Intégration économique et unification du droit privé", in De Conflictu Legum - Essays presented to KOLLEWIJN and OFFERHAUS (Leyden: A. W. Sijthoff, 1962), 198.; Sergio Cámara Lapuente, "Un derecho privado o un código civil para Europa: planteamiento, nudo y (esquivo) desenlace", in Derecho Privado Europeo, ed. Sergio Cámara Lapuente (Madrid: Editorial Colex, 2003), 68: "normalmente la unión monetaria y aduanera acaban conduciendo a un Código uniforme”; Luís de Lima Pinheiro, Direito internacional privado - Vol. 1, Introdução e Direito de Conflitos - Parte Geral (Coimbra: Almedina, 2014), 411, and "Direito aplicável às operações bancárias internacionais", in Estudos de Direito Internacional Privado (Coimbra: Almedina, 2009), 235; Maria Helena Brito, "O Regulamento (CE) no. 2201/2003, do Conselho, de 27 de Novembro de 2003, relativo à competência, ao reconhecimento e à execução de decisões em matéria matrimonial e em matéria de responsabilidade parental", in Estudos em Memória do Professor Doutor António Marques dos Santos, ed. Luís de Lima Pinheiro, Dário Moura Vicente, and Jorge Miranda (Coimbra: Almedina, 2005), 309; Mário Júlio Almeida Costa, "Alienação fiduciária em garantia e aquisição de casa própria", Direito e Justiça - Revista da Faculdade de Ciências Humanas da Universidade Católica Portuguesa I, no. 1 (1980): 41; Nuno Andrade Pissarra, "Normas de aplicação imediata e direito comunitário", in Normas de Aplicação Imediata, Ordem Pública Internacional e Direito Comunitário (Coimbra: Almedina, 2004), 47; José Carlos Fernández Rozas and Sixto Sánchez Lorenzo, Curso de Derecho Internacional Privado (Madrid: Editorial Civitas, 1996), 158; Pedro Miguel Asensio, "Integración europea y derecho internacional privado", Revista de Derecho Comunitario Europeo 1, no. 2 (1997): 414; Ulrich Drobnig, "Unified rules on proprietary security - in the world and in Europe", Boletim da Faculdade de Direito da Universidade de Coimbra LXXXV (2009): 669, and "Scope and general rules of a European Civil Code", European Review of Private Law 5, no. 4 (1997): 489; Antoni Vaquer Aloy, “'Armonización del derecho privado en Europa vs. codificación del derecho civil en Cataluña?”, in Estudios Jurídicos en Homenaje al Profesor Luis Díez-Picazo, ed. Antonio Cabanillas Sánchez (Madrid: Civitas - Thomson, 2003), 1055; Roy Goode, “A credit law for Europe", International and Comparative Law Quarterly 23 (1974): 251; Harry Duintjer Tebbens, "Private international law and the Single European Market: Coexistence or cohabitation", in Forty Years On: The Evolution of Postwar Private International Law in Europe (Daventer: Kluwer - University of Amsterdam, 1990), 49; José Maria Gondra Romero, "Integración económica e integración jurídica en el marco de la Comunidad Europea, desde una perspectiva sistemático-funcional", in Tratado de Derecho Comunitario Europeo, ed. Eduardo García de Enterría, Julio González Campos, and Santiago Muñoz Machado (Madrid: Editorial Civitas, 1986), 275-276.

${ }^{4}$ Cf. Afonso Patrão, Autonomia Conflitual..., 360. 
powers discovered a new approach to harmonisation: mutual recognition was seen as an alternative to unification, more harmonious with subsidiarity and proportionality principles. In fact, mutual recognition assumes an equivalence between different laws of Member States, ${ }^{5}$ ensuring economic agents that the compliance to the law of the Member State of origin shall grant the right of selling a good or performing a service in all EU. Such principle makes it non-compulsory to unify rules in different Member States: it is enough to comply with the law of the Member State of origin in order to perform activity in all the EU, which would keep legal diversity without its inherent problems. ${ }^{6}$

Said differently: mutual recognition involves the conclusion that unification or harmonisation of legislations is not always the most accurate way of accomplishing the internal market, making it possible to limit the approximation of legislations to a minimum. Legal diversity is not necessarily an obstacle to the freedoms of circulation, being possible (or even desirable) to achieve an Economic and Monetary Union within distinct legal systems, as long as economic operators are not bound to comply with foreign divergent rules. ${ }^{7}$

\footnotetext{
${ }^{5}$ Cf. António Frada de Sousa, A Europeização do Direito Internacional Privado (Porto: policopied, 2012), 196; Helène Gaudemet-Tallon, "De nouvelles fonctions pour l'équivalence en droit international privé?”, in Le Droit International Privé: Esprit et Méthodes (Paris: Dalloz, 2005), 317.

${ }^{6}$ Stressing out mutual recognition as an alternative to harmonisation, cf. Luís de Lima Pinheiro, "Concorrência entre sistemas jurídicos na União Europeia e direito Internacional Privado", $O$ Direito, no. II (2007), 256; Mónica Guzmán Zapater, "El principio del reconocimiento mutuo: ¿Un nuevo modelo para el derecho internacional privado comunitario?", Revista de Derecho Comunitario Europeo 3 (1998), 141 and François Rigaux and Marc Fallon, Droit International Privé (Bruxelas: De Boeck \& Larcier, 2005), 164; Esther Muñiz Espada, Bases para una Propuesta de Eurohipoteca (Valencia: Ed. Tirant lo Blanch, 2005), 81; Daniel Vignes, "Le rapprochement des législations”, in Commentaire J. Mégret - Le Droit de la CEE, Vol. 5 - Dispositions Fiscales. Rapprochement des Législations (Éditions de l'Université de Bruxelles - Institut d'Études Européennes, 1993), 358, and "Remarques sur la double nature de la reconnaissance mutuelle", in Hacia un Nuevo Orden Internacional y Europeo - Estudios en Homenaje al Profesor Don Manuel Díez de Velasco, ed. Manuel Pérez Gonzáles, et al. (Madrid: Tecnos, 1993), 1295.

${ }^{7}$ Marc Fallon, "Les conflits de lois et de juridictions dans un espace économique intégré - L'expérience de la Communauté Européenne”, Recueil des Cours de l’Académie de Droit International 253 (1995): 212; Mónica Guzmán Zapater, "El principio....", 141; Luís de Lima Pinheiro, "Concorrência....", 264; Alfonso Mattera, "L'élimination des barrières techniques et la mise en oeuvre de la reconnaissance mutuelle", Revue du Marché Commun 334 (1990): 92. According to Dário Moura Vicente, "Liberdades comunitárias e direito internacional privado", Revista da Ordem dos Advogados year 69 (2009), 762 and 787, mutual recognition is explained on the idea of regulatory competition. Also, Hans-Bernd Schäfer and Katrin Lantermann, "Choice of law from an economic perspective", in An Economic Analysis of Private International Law, ed. Jürgen Basedow and Toshiyuki Kono (Tübingen: Mohr Siebeck, 2006), 96; Horst Eidenmüller,
} 
When applied to private law - which the ECJ expressly $\mathrm{did}^{8}$-, the nature of mutual recognition is debatable: some writers sustain it is a hidden rule on the conflict of laws, ascertaining an alternative connection in favour of the economic freedom (favor offerentis) between the application of the law of the country of origin and the law applied in the country of destination; ${ }^{9}$

"Free choice in international corporate law: European and German corporate law in European competition between corporate law systems", in An Economic Analysis of Private International Law, ed. Jürgen Basedow and Toshiyuki Kono (Tübingen: Mohr Siebeck, 2006), 190.

${ }^{8}$ In fact, despite the origin of mutual recognition in public law domains - built on the idea of mutual trust - the ECJ quickly applied the principle in private law, which is especially clear in Judgment of 1 July 1993, Hubbard, C-20/92, Colectânea da Jurisprudência, 1993, I-3777, \$\$19 and 20: "the effectiveness of Community law cannot vary according to the various branches of national law which it may affect. In this case, the national law affected by Community law is not the law relating to the substantive proceedings but national procedural law. The reply to this question must therefore be that the fact that the substantive proceedings come under the law of succession does not justify excluding the application of the right to freedom to provide services enshrined in Community law with respect to a member of a profession responsible for the case".

Stressing out the application of mutual recognition to private law, cf. Dário Moura Vicente, "Liberdades comunitárias...", 763; António Frada de Sousa, A Europeização..., 239; Luca G. Radicati di Brozolo, "L'influence sur les conflits de lois des principes de droit communautaire en matière de liberté de circulation”, Revue Critique de Droit International Privé 82, no. 3 (1993): 407; François Rigaux and Marc Fallon, Droit International Privé, 763; Jürgen Basedow, "EC conflict of laws - A matter of coordination", in Seminário Internacional sobre a Comunitarização do Direito Internacional Privado - Direito de Conflitos, Competência Internacional e Reconhecimento de Sentenças Estrangeiras, ed. Luís de Lima Pinheiro (Coimbra: Almedina, 2005), 23; Isabelle Barrière Brousse, "Le Traité de Lisbonne et le droit international privé", Journal du Droit International 1 (2010): 15. Criticising the applicability of this principle to private law, Luís de Lima Pinheiro, Direito Internacional..., 396; "O direito de conflitos e as liberdades comunitárias de estabelecimento e de prestação de serviços”, in Seminário Internacional sobre a Comunitarização do Direito Internacional Privado - Direito de Conflitos, Competência Internacional e Reconhecimento de Sentenças Estrangeiras, ed. Luís de Lima Pinheiro (Coimbra: Almedina, 2005), 91 and 95; Bernard Audit and Louis d'Avout, Droit International Privé (Paris: Economica, 2010), 60; Vincent Heuzé, "De la compétence de la loi du pays d'origine en matière contractuelle ou l'anti-droit européen", in Le Droit International Privé: Esprit et Méthodes (Paris: Dalloz, 2005), 412.

${ }^{9}$ Jürgen Basedow, "Der kollisionsrechtliche Gehalt der Produktfreiheiten im europäischen Binnenmarkt: favor offerentis", Rabels Zeitschrift für ausländisches und internationales Privatrecht 59, no. 1 (1995): 5, 12-13, 25; "EC conflict of laws - A matter of coordination", 25; Alegría Borrás, "Le droit international privé communautaire: Réalités, problèmes et perspectives d'avenir", Recueil des Cours de l'Académie de Droit International, 317 (2005): 375: "l'effet de ce principe est similaire à celui d'une règle de conflit de lois, car il mène à l'application de la loi de l'État d'origine"; Arnaud Nuyts, "Lapplication des lois de police dans l'espace (Réflexions au départ du droit belge de la distribution commerciale et du droit communautaire)", Revue Critique de Droit International Privé 88 (1999): 256 "ce principe d'équivalence et de reconnaissance mutuelle se prête à un rapprochement avec la technique du rattachement alternative, propre au droit international privé"; Jan von Hein, "Of older siblings and distant cousins: The contribution of the Rome II Regulation to the communitarisation of private international law", Rabels Zeitschrift für ausländisches und internationales 
other writers believe it is a substantive limitation to the application of the law of the country of destination (or the applicable law pointed out by its national rules on the conflict of laws), whenever it is possible to assume the existence of an equivalence of legislations ${ }^{10}$ Regardless of nature - which

Privatrecht 73, no. 3 (2009): 476; Andrea Bonomi, "Le droit international privé entre régionalisme et universalisme", Revue Suisse de Droit International et Européen 16, no. 3 (2006): 303; Christoph Schmid, "Options under EU Law for the implementation of a eurohypothec", in Basic Guidelines for a Eurohypothec - Outcome of Eurohypothec Workshop November 2004/April 2005, ed. Agnieszka Drewics-Tulodzieca (Warsaw: Mortgage Credit Foundation, 2005), 62; Horatia Muir Watt, "The challenge of market integration for European conflicts theory", in Towards a European Civil Code, ed. Arthur Hartkamp, et al. (Haia: Kluwer Law International, 2004), 201: "the new rules pre-empt divergent national conflicts solutions, and apply whatever the nature of the measures involved (public/private; mandatory/default"; José Carlos Fernández Rozas and Sixto Sánchez Lorenzo, Curso..., 181: "El principio de origen es consecuencia inmediata de las necesidades de la integración: de hecho, se opone a la regla de DIPr general en los marcos no integrados"; Janis Leifeld, Das Anerkennungsprinzip im Kollisionsrechtssystem des internationalen Privatrechts (Tübingen: Mohr Siebeck, 2010), 180.; Stefan Grundmann, "Binnenmarktkollisionsrecht - vom klassischen IPR zur Integrationsordnung", Rabels Zeitschrift für ausländisches und internationales Privatrecht 64, no. 3 (2000): 460-461; Ralf Michaels, "The new European choice-of-law revolution", Tulane Law Review 82, no. 5 (2008): 1627; Roberto Baratta, "Problematic elements of an implicit rule providing for mutual recognition of personal and family status in the EC", IPRax - Praxis des Internationalen Privat und Verfahrensrechts 1 (2007): 9 "The functioning of the principle implies certain consequences. First, the domestic conflict-of-laws and substantive rules should not be applied if they lead to a non-recognition result. Therefore, the principle operates, on the one hand, as a waiver of the domestic rules and, on the other hand, as a special rule of coordination between the member states' legal systems"; E. Crabit, "La directive sur le commerce électronique. Le project 'mediterrané', Revue de Droit de l'Union Européenne 4 (2000): 750.

There are signs of ECJ case-law pointing out this nature: Judgment of 4 December 1986, Commission v. Germany - Insurance, Case 205/84, EU:C:1986:463, paragraph 41, on the applicability of requirements of German insurance law not demanded by the law of the country of origin; Judgment of 9 August Vander Elst, C-43/93, 1994, I-3803, paragraphs 18 ff., on the applicability of prerequisites of the law of country of destination on protection of workers; Judgment 10 May 1995, Alpine Investments, C-384/93, 1995, I-1141, paragraph 48, ascertaining the applicability of the law of country of origin to cold calling activities.

${ }^{10}$ Luca G. Radicati di Brozolo, "Libre circulation dans la CE et règles de conflit", in L'Européanisation $d u$ Droit International Privé, ed. Paul Lagarde and Bernd von Hoffmann (Köln: Bundesanzeiger, 1996), 93, and “''influence...", 409: "l'application de ces principes ne signifie pas un bouleversement complet du fonctionnement du droit international privé [...]. Les principes en question n’interdissent pas systématiquement l'application de la loi du pays d'accueil, et il est donc impossible d'en déduire une obligation générale d'appliquer toujours la loi du pays d'origine, ce qui, effectivement, équivaudrait au remplacement des règles de conflits"; Mathias Audit, "Régulation du marché intérieur et libre circulation de lois", Journal du Droit International 4 (2006): 1342 "cette prépondérance conférée au principe de reconnaissance mutuelle et l'introduction d'un critère d'équivalence [...] ne modifie en rien le constat selon lequel ce sont toujours les règles de l'État de destination qui sont sanctionnées au titre de mesures d'effet équivalant à de restrictions quantitatifs. Si les règles du pays d'origine sont invoquées, c'est uniquement pour faire état de leur 'équivalence' avec celles que prévoit l'État d'importation, ce constat permettant de les écarter”; Mónica Guzmán Zapater, “El principio...”, 148, 


\section{is dubious due to somewhat rambling ECJ case-law ${ }^{11}-$, it is clear that the principle of mutual recognition entails amendments on the legal standards}

and "Un elemento federalizador para Europa: el reconocimiento mutuo en el ámbito del reconocimiento de decisiones judiciales", Revista de Derecho Comunitario Europeo 10 (2001): 417-418; Hans Jürgen Sonnenberger, "Europarecht und internationales Privatrecht", Zeitschrift für vergleichende Rechtswissenschaft: Archiv für internationales Wirtschaftsrecht 1 (1996): 11-13; Vincent Heuzé, "De la compétence de la loi du pays d'origine en matière contractuelle ou l'anti-droit européen", 395; Christian Kohler, "La Cour de Justice des Communautés Européennes et le droit international privé", Travaux du Comité Français de Droit International Privé (1993-1995): 76, and "La reconnaissance de situations juridiques dans l'Union Européenne: Le cas du nom patronymique", in La Reconnaissance des Situations en Droit International Privé, ed. Paul Lagarde (Paris: Pedone, 2013), 72; Michel Tison, "Unravelling the general God exception: The case of financial services", in Services and Free Movement in EU Law, ed. Mads Andenas and Wulf-Henning Roth (Oxford: Oxford University Press, 2002), 371; Pascal de Vareilles-Sommières, "La communautarisation du droit international privé des contrats: Remarques en marge de l'uniformisation européenne du droit des contrats", in Le Droit International Privé: Esprit et Méthodes (Paris: Dalloz, 2005), 795; Harry Duintjer Tebbens, "Les conflits de lois en matière de publicité déloyale à l'épreuve du droit communautaire", Revue Critique de Droit International Privé 83, no. 3 (1994): 474-475; Sylvaine PoillotPeruzzetto, "Comentário ao Acórdão do Tribunal de Justiça de 2 de Outubro de 2003, Garcia Avello, proc. C-148/02”, Journal du Droit International 131, no. 4 (2004): 1236; Wulf-Henning Roth, "Der Einfluß des Europäischen Gemeinschaftsrechts auf das internationale Privatrecht”, Rabels Zeitschrift für ausländisches und internationales Privatrecht 55, no. 4 (1990): 668-669, and "Secured credit and the internal market: The fundamental freedoms and the EU's mandate for legislation": 44; Peter von Wilmowsky, "EG-Vertrag und kollisionsrechtliche Rechtswahlfreiheit", Rabels Zeitschrift für ausländisches und internationales Privatrecht 62, no. 1 (1998): 11; Martin Gebauer, "Internationales Privatrecht und Warenverkehrsfreiheit in Europa", IPRax - Praxis des Internationalen Privat und Verfahrensrechts 15, no. 3 (1995): 154; Alain Gourio, "Le nouveau...", 139.

${ }^{11}$ In fact, in Judgment of 5 November 2002 Überseering, C-208/00, and in Judgment of 30 September 2003, Inspire Art, C-167/01, the ECJ leaves undecided if it demanded the obligation for the Member State of destination to recognise the society created abroad or if it was imposing a new rule on the conflict of laws, establishing the application of the law of the country where the society was created (incorporation theory) - Rafael Arenas García, "Sombras y luces en la jurisprudencia del Tribunal de Justicia de la Unión Europea en materia de DIPr de sociedades", in Nuevas Fronteras del Derecho de la Unión Europea - Liber Amicorum José Luis Iglesias Buhigues, ed. Carlos Esplugues Mota and Guillermo Palao Moreno (Valencia: Tirant lo blanch, 2012), 750-754; Paul Lagarde, "Comentário ao Acórdão do Tribunal de Justiça de 5 de Novembro de 2002, Überseering, proc. C-208/00”, Revue Critique de Droit International Privé 92, no. 3 (2003): 534; Maria Ângela Bento Soares, "A liberdade de estabelecimento das sociedades na União Europeia”, Temas de Integração, 15-16 (2003): 298, and "O Acórdão Inspire Art Ltd: Novo incentivo jurisprudencial à mobilidade das sociedades na União Europeia", Temas de Integração 17 (2004): 140; Anne Röthel, "Internationales Sachenrecht im Binnenmarkt", Juristen Zeitung (JZ) 58, no. 21 (2003): 1030; Michael Grünberger, "Alles obsolet? - Anerkennungsprinzip vs. klassisches IPR", in Brauchen wir eine Rom 0-Verordnung?, ed. Stefan Leible and Hannes Unberath (Jena: Jenaer Wissenschaftliche Verlagsgesellschaft, 2013), 90; Paschalis Paschalidis, Freedom of Establishment and Private International Law for Corporations (Oxford: Oxford University Press, 2012), 46.; Jan von Hein and Giesela Rühl, “Towards a European code on private international law", in Cross-Border Activities in the EU - Making Life Easier for Citizens, ed. Directorate General for Internal Policies (Brussels: European Parliament, 2015), 19. 
which may be demanded in the country of origin, favouring the economic freedoms despite legal diversity.

As sustained elsewhere, it seems proper to describe mutual recognition as very similar to the theory of vested rights, compelling the Member State of destination to ensure a right granted by the country of origin. Regardless of the applicable law, the right granted by the country of origin shall be respected by the country of destination. ${ }^{12}$ In fact, pursuant to ECJ judg-

${ }^{12}$ Cf. Afonso Patrão, Autonomia Conflitual..., 451.; Ralf Michaels, "EU law as private international law? Maastricht the country-of-origin principle as vested-rights theory", Journal of Private International Law 2, no. 2 (2006): 198 "the country of origin principle displays a remarkable degree of similarity to an old approach that almost has been forgotten. This approach is known as the vested-rights theory"; Paul Lagarde, "La reconnaissance: mode d'emploi", in Vers de Nouveaux Équilibres entre Ordres Juridiques - Mélanges en L’Honneur de Helène Gaudemet-Tallon (Paris: Dalloz, 2008), 482.; "Comentário ao Acórdão do Tribunal de Justiça de 14 de Outubro de 2008 Grunkin e Paul, proc. C-353/06”, Revue Critique de Droit International Privé 98, no. 1 (2009), 92: "Développements futurs du droit international privé dans une Europe en voie d'unification: quelques conjectures", Rabels Zeitschrift für ausländisches und internationales Privatrecht 68, no. 2 (2004): 227; Louis d'Avout, "Comentário ao Acórdão do Tribunal de Justiça de 14 de Outubro de 2008 Grunkin e Paul, proc. C-353/06”, Journal du Droit International 1 (2009): 208; Erik Jayme, "Il diritto internazionale privato nel sistema comunitario e i suoi recenti sviluppi normativi nei rapporti con Stati terzi”, Rivista di Diritto Internazionale Privato e Processuale 2 (2006): 360; Peter Mankowski, "Binnenmarkt-IPR - Eine Problemskizze", in Aufbrucht nach Europa: 75 Jahre MaxPlanck-Institut für Privatrecht, ed. Jürgen Basedow, et al. (Tubingen: Mohr Siebeck, 2001), 602-603; Michael Wilderspin and Xavier Lewis, "Les relations entre le droit communautaire et les règles de conflits de lois des États membres", Revue Critique de Droit International Privé 91, no. 1 (2002): 18; Luca G. Radicati di Brozolo, "L'influence sur les conflits de lois des principes de droit communautaire en matière de liberté de circulation”, Revue Critique de Droit International Privé 82, no. 3 (1993): 421; Javier Carrascosa González, "La autonomía de la voluntad en la contratación internacional", in Autonomía de la Voluntad en el Derecho Privado - Estudios en Conmemoración del 150 Aniversario de la Ley del Notariado, ed. Lorenzo Prats Albentosa (Madrid: Consejo General del Notariado - Wolters Kluwer España, 2013), 644: "el principio del mutuo reconocimiento se basa en una técnica clásica del Derecho internacional privado: el 'conflicto de sistemas'. Que significa lo siguiente: no es relevante la Ley que sea dicha aplicada, la situación legalmente creada y existente en un Estado miembro, se considerará válidamente existente en los demás Estados miembros"; Alfonso Luis Calvo Caravaca and Javier Carrascosa González, Derecho Internacional..., 76-79; Bernard Audit and Louis dAvout, Droit..., 59; Mónica Guzmán Zapater, "El principio...”, 151: “Es posible que nos hallemos ante un incipiente sistema de DIPr basado en la idea de reconocimiento de un derecho o de una situación consolidada en el extranjero - que, potenciado por la falta de normas comunitarias de DIPr, responde a exigencias propias del Mercado Interior"; Jeremy Heymann, Le Droit International Privé à L'Épreuve du Fédéralisme Européen (Paris: Economica, 2010), 239; María Dolores Ortiz Vidal, "El caso Grunkin-Paul: Notas a la STJUE de 14 de octubre de 2008", Cuadernos de Derecho Transnacional 1, no. 1 (2009): 147; "Espacio judicial europeo y Tratado de Lisboa: Hacia un nuevo derecho internacional privado", Cuadernos de Derecho Transnacional 2, no. 1 (2010): 395; Matteo Ortino, "The role and functioning of mutual recognition in the European market of financial services”, International and Comparative Law Quarterly 56, no. 2 (2007): 
ment Grunkin \& Paul, the Member State of destination was held to recognise a legal situation (the name of a person) established according to a different applicable law. ${ }^{13}$

However, mutual recognition not always engenders the solution to legal diversity.

On the one hand, because it is a legal principle intended to endorse the creation of an internal market, mutual recognition is applied only when the rules enforced in the destination country trigger obstacles to the basic freedoms, not being employed whenever the law of the country of destination is more tolerant with regard to the rules unconnected to the European freedoms. ${ }^{14}$

320-321; Christian Kohler, "La reconnaissance de situations juridiques dans l'Union européenne: le cas du nom patronymique", 72: "il s'agit de donner effet à la situation juridique déterminée dans l'État membre d'origine sans égard à la loi appliquée" ; Heinz-Peter Mansel, "Anerkennung als Grundprinzip des Europäischen Rechtsraums", Rabels Zeitschrift für ausländisches und internationales Privatrecht 70, no. 4 (2006): 724.

${ }^{13}$ In fact, in Judgment of 14 October 2008, Grunkin \& Paul, Case, C-353/06, EU:C:2008:559, \$39, the ECJ ascertained the determination of the name of a child according to the rule on the conflict of law of the country of destination - nationality of the child - would be a restriction to the freedom of movement of people because it would result in a different name vis-à-vis the name established by the country of origin. Cfr. $\$ 39$, stating the basic freedoms "preclude the authorities of a Member State, in applying national law, from refusing to recognise a child's surname, as determined and registered in a second Member State in which the child - who, like his parents, has only the nationality of the first Member State - was born and has been resident since birth", confirming the obligation to recognise the vested right. Also, Rui Moura Ramos, "A evolução recente do direito internacional privado da família", in Direito da Família e Direito dos Menores: Que Direitos no Século XXI?, ed. Maria Eduarda Azevedo and Ana Sofia Gomes (Lisboa: Universidade Lusíada Editora, 2014), 77; António Frada de Sousa, A Europeização..., 286; Luís de Lima Pinheiro, Direito Internacional..., 393; Paul Lagarde, “Comentário ao Acórdão Grunkin e Paul...”, 91-92; Christian Kohler, “La reconnaissance de situations juridiques dans l’Union Européenne: Le cas du nom patronymique", 76; Paschalis Paschalidis, Freedom..., 68. This specific understanding of the nature of mutual recognition was received by German Law in the new $\$ 48$ EGBGB: Notwithstanding the applicable law to the formation of the name, the name registered in other Member States is recognised.

${ }^{14}$ Cf. Paul Lagarde, "La reconnaissance: mode d'emploi", 483: "Il n'impose la reconnaissance que dans les cas où la non-reconnaissance serait une entrave non justifiée par l'intérêt général aux grandes libertés du traité"; Marc Fallon and Johan Meeusen, "Private international law in the European Union and the exception of mutual recognition", Yearbook of Private International Law 4 (2002), 57; Mathias Audit, "Régulation...”, 1347. On the interference of mutual recognition only when the law of the country of origin is more indulgent, cf. the example by Peter von Wilmowsky, "EG-Vertrag...", 14: before the harmonisation of rules on the pollution of vehicles, in Germany cars were built for other Member States without respecting the environmental requirements of German law (country of origin), since the countries of destination did not demand such conditions. 
On the other hand, there are several causes authorising the receiving country to discharge mutual recognition. Application of the law of the country of destination is allowed, even if restraining European freedoms, granted that these rules are justified by overriding requirements relating to the public interest and applicable to all persons and undertakings operating in the territory of the State. ${ }^{15}$

Finally, according to the ECJ's case-law, the relevance of mutual recognition is limited to the cases where an equivalence of legislations can be found, not being imposed when different rules of the country of origin and the country of destination pursue unlike purposes. ${ }^{16}$

In the ECJ case-law, this is specially obvious in Judgment Überseering (cit. fn 9), $\$ \$ 78$ to 82 , where the ECJ reflects on the restricting results of the application of a different law to the society, settling the impossibility of refusal of the legal capacity of a company to establish itself in another Member State; and in Judgment of 30 March 1993, Konstantinidis, C-168/91, \$15, where the ECJ decides that the result of the rules on transliteration of German law "interfere with his freedom to exercise the right of establishment" (cf. Marta Requejo Isidro, "Libertades comunitarias y registro civil: Algunos casos de incidencia mutua y pautas de solución", in Derecho Registral Internacional Homenaje a la Memoria del Profesor Rafael Arroyo Monteiro, ed. Pedro Miguel Asensio (Madrid: Iprolex, 2003),ed. Pedro Miguel Asensio (Madrid: Iprolex, 2003 100. In fact, the principle of mutual recognition acts only when the country of destination would obstruct one of the basic freedoms. ${ }^{15}$ Cf. Ralf Michaels, "EU Law...", 224; Mathias Audit, "Régulation...", 1343. In accordance, the ECJ declared the possibility of application of restraining rules in Judgment of 24 November 1993, Keck and Mithouard, C-267/91 and C-268/91, EU:C:1993:905, \$16; Judgment of 24 October 1978, Société générale alsacienne de banque SA v.Walter Koestler, Case 15/78, EU:C:1978:184; Judgment of 3 February, Société anonyme de droit français Seco and Others $v$. Etablissement d'assurance contre la vieillesse et l'invalidité, Case 62/81 and 63/81, EU:C:1982:34 \$8; Judgment of 8 March 1980, Procurer du Roi v.Debauve and Others, Case 52/79, EU:C:1980:83 \$15; Judgment of 17 December 1981, Alfred John Webb, Case 279/80, EU:C:1981:314, \$17; Judgment of 15 de March de 2001, André Mazzoleni and Inter Surveillance Assistance SARL, Case C-165/98, EU:C:2001:162, \$\$24-25; Judgment of 25 October 2001, Finalarte Sociedade de Construção Civil Lda., Case C-49/98, C-50/98, C-52/98 to C-54/98 and C-68/98 to C-71/98, EU:C:2001:564, $\$ \$ 28$ ff.; Judgment of 24 January 2002, Portugaia Construções Lda., C-164/99, EU:C:2002:40, \$21; Judgment of 12 October 2004, Wolff \& Müller GmbH v. José Filipe Ferreira Félix, C-60/03, EU:C:2004:610, \$\$32 ff. On this case-law, cf. Helène Gaudemet-Tallon, "De nouvelles fonctions pour l'équivalence en droit international privé?", 318; Martin Gebauer, "Internationales...", 154. A more extensive analysis of the limits of mutual recognition can be found in Afonso Patrão, Autonomia Conflitual..., 465.

${ }^{16}$ Cf. Rafael Arenas García, "Abolition of exequatur: Problems and solutions - mutual recognition, mutual trust and recognition of foreign judgments: too many words in the sea", Yearbook of Private International Law 12 (2010): 363 "the rules of the State of origin must be equivalent to the rules of the State of destination. Without this equivalence, mutual recognition does not work"; Luca G. Radicati di Brozolo, "L'influence...”, 423; Peter von Wilmowsky, "EG-Vertrag...", 15; Catherine Barnard, The Substantive Law of the EU - The Four Freedoms (Oxford: Oxford University Press, 2004), 105; José Ignacio Paredes Pérez, "Alcance y contenido de la noción de equivalencia en el derecho internacional privado", Anuario Español de Derecho Internacional 
In all these situations, economic agents shall comply with the law of the destination country, being therefore compelled to adjust to different legal systems. Which means mutual recognition does not overcome all difficulties inherent to legal diversity in the European Union. Furthermore, the method of mutual recognition is questionable, since it benefits economic agents from the countries with less severe standards, encouraging Member States to adopt laidback rules - in the context of a regulatory competition. ${ }^{17}$

\section{Private International Law as a tool towards the internal market}

Besides choosing the most closely connected legislation to an international situation, it is clear that the rules on the conflict of laws play a role in the substantial outcome of a juridical problem, either by choosing the applicable law considering its effects, or by taking account of the political interests of the involved countries. ${ }^{18}$

Privado XII (2012): 118; Matteo Ortino, “The role...", 313-317; Stefania Bariatti, "Reconnaissance et droit de l'Union Européenne”, in La Reconnaissance des Situations en Droit International Privé, ed. Paul Lagarde (Paris: Pedone, 2013), 61. In fact, the equivalence of policies as a condition of mutual recognition is stressed out in Judgments Webb (cit. footnote 13) \$\$17; Mazzoleni (cit. footnote 13) $\$ \$ 24-25$ and Finalarte (cit. footnote 13) $\$ \$ 28 \mathrm{ff}$.

${ }^{17}$ Cf. António Marques dos Santos, "Direito aplicável aos contratos celebrados através da internet e tribunal competente", in Estudos de Direito Internacional Privado e de Direito Público (Coimbra: Almedina, 2004), 116: "uma alternativa neoliberal à harmonização das legislações dos EstadosMembros - um 'novo paradigma', já que conduz a uma concorrência entre ordens jurídicas diferentes no sentido da adopção dos níveis de protecção mais baixos"; Jesús Alfaro Águila-Real, "La unificación del derecho privado en la Unión Europea: Perspectiva”, in Derecho Privado Europeo, ed. Sergio Cámara Lapuente (Madrid: Editorial Colex, 2003), 116; Onno Brouwer, "Free movement of foodstuffs and quality requirements: Has the Commission got it wrong?", Common Market Law Review 25, no. 2 (1988): n. 2 (1988 257; Maria Dakolias, “The Second Banking Directive: The issue of reciprocity”, Legal Issues of European Integration 18, no. 2 (1991): 74; Mónica Guzmán Zapater, "El principio...", 138-139; Norbert Reich, “Competition between legal orders: A new paradigm of EC Law?", Common Market Law Review 29, no. 5 (1992), 863.

In fact, this deregulatory effect was clear in Germany, when this Member State aligned its rules on the purity of beers with less demanding rules of other Member States, trying not to cause harm on German manufacturers - António Frada de Sousa, A europeização..., 685. Therefore, a balance must be found in the limits of mutual recognition, which is of major difficulty - Catherine Barnard and Simon Deakin, "Market access and regulatory competition", Jean Monnet Working Papers 9 (2001): 14 .

${ }^{18}$ This is very clear in the rules on the conflict of laws in situations where parties are regarded as being weaker, making applicable the law which offers the most intensive protection - cf. article 6 and 8 of Regulation (EC) 597/2008 (Rome I); and article 5 of Regulation (EC) 864/2007 (Rome II). On the trend of choosing the applicable law according to the substantive result, cf. Rui Moura Ramos, "La protection de la partie contractuelle la plus faible en droit international privé portugais", in Das Relações Privadas Internacionais - Estudos de Direito Internacional Privado (Coimbra: 
Furthermore, rules on the conflict of laws obey to political interests: when choosing a connecting factor, as long as the classical goals of private international law are fulfilled, ${ }^{19}$ governmental purposes are taken into account. ${ }^{20}$ These policies are not exclusively the determination of the country which has the strongest connection to an international situation.

On the one hand, when the parties are allowed to choose the applicable law, the physical location is disregarded, valuing the interests of the individuals and the goals of international commerce instead. ${ }^{21}$

On the other hand, the selection of the connecting factor often aims the accomplishment of a certain governmental policy. The classical example is the choice between the law of nationality and habitual residence: emigration countries have a tendency to establish the rule of nationality, keeping a connection to its citizens who moved abroad; immigration countries lean towards the rule of habitual residence, maximising the application of lex fori and promoting the integration in the society of the receiving State. ${ }^{22}$ Furthermore, a clear trend of appearance of semipublic law can be

Coimbra Editora, 1995), 197; Julio González Campos, "El paradigma de la norma de conflicto multilateral", in Estudios Jurídicos en Homenaje al Profesor Aurelio Menéndez (Madrid: Civitas, 1996), 5267. These concerns have their roots in the influence of American case-law and writers - cf. António Ferrer Correia, Direito Internacional Privado - Alguns Problemas (Coimbra: Almedina, 1997), 25; Henri Batiffol, "De l'usage des principes en droit international privé", in Estudos em Homenagem ao Prof. Doutor A. Ferrer-Correia (Coimbra: Faculdade de Direito da Universidade de Coimbra, 1986), 112; Erik Jayme, "Identité culturelle et intégration: Le droit international privé postmoderne", Recueil des Cours de l'Académie de Droit International, 251 (1995): 45.

${ }^{19}$ Among others, the principles of international harmony of decisions; substantial harmony of different applicable laws; effectiveness of decisions; and equal treatment of legal systems.

${ }^{20}$ Cf. António Ferrer Correia, Direito Internacional... (1997), 121; M. Aguilar Navarro, "Algunos supuestos politicos del derecho internacional privado", Revista Española de Derecho Internacional XIII, no. 1-2-3 (1960): 63; Henri Batiffol, "L'état du droit international privé en France et dans l'Europe continental de l'Ouest", in Choix d'Articles. Rassemblés par ses amis (Paris: LGDJ, 1976), 29; Aspects Philosophiques du Droit International Privé (Paris: Dalloz, 1956), 228.

${ }^{21}$ On the nature of party autonomy as a connecting factor, cf. Dário Moura Vicente, A Tutela Internacional da Propriedade Intelectual (Coimbra: Almedina, 2008), 289: "a autonomia da vontade constitui, assim, no Direito Internacional Privado, um princípio distinto do da proximidade [...] prevalecendo sobre este no seu domínio próprio de aplicação"; François Rigaux, "Les situations juridiques individuelles dans un système de relativité générale - Cours général de droit international privé", Recueil des Cours de l'Académie de Droit International 1989-I, Tomo 213 (1989): 175. ${ }^{22}$ Cf. Bernard Audit, "Le droit international privé à la fin du XX siècle: progrès ou recul", Revue Internationale de Droit Comparé 50, no. 2 (1998): 425; Jürgen Basedow, "The communitarisation of private international law", Rabels Zeitschrift für ausländisches und internationales Privatrecht 73, no. 3 (2009): 458; "15 years of European private international law - achievements, conceptualization and outlook", in Entre Bruselas y la Haya: Estudios Sobre la Unificación Internacional y Regional del Derecho Internacional Privado - Liber Amicorum Alegría Borrás, ed. Joaquin Forner 
found, often internationally mandatory norms (lois d'application immédiate), unilaterally establishing their scope of application and modifying the system of the conflict of laws with the aim of achieving particular goals of the involved States. ${ }^{23}$

In fact, private international law is not formed exclusively by purely localising rules but adopts connecting factors which promote certain policies: "private international law is now losing the 'innocence' which served traditionally to keep it sheltered from the intrusion of state interests". ${ }^{24}$

Delaygua, Cristina González Beilfuss, and Ramón Viñas Farré (Madrid: Marcial Pons, 2013), 181; Pierre Gannagé, "La pénétration de l'autonomie de la volonté dans le droit international privé de la famille", Revue Critique de Droit International Privé 81, no. 3 (1992), 428-429; Herbert Kronke, "Connecting factors and internationality in conflict of laws and transnational commercial law", in Convergence and Divergence in Private International Law - Liber Amicorum Kurt Siehr, ed. Katharina Boele-Woelki, et al. (Zurique: Schulthess, 2010), 59: "While a legal system that favours integration of migrant populations into the local society may opt for domicile, a system that attaches greater importance to maintaining a person's ties to his or her country of origin will, in general and subject to the law of citizenship, hold on to nationality as the principal connecting factor"; J.-P. Niboyet, "Le Code Civil en préparation et les règles de solution des conflits de lois”, Travaux du Comité Français de Droit International Privé Année 7 (1945-1946): 30, sustaining Private International Law as "une branche du droit politique d’un État"; M. Aguilar Navarro, "Algunos...", 46; Nuno Ascensão Silva, "Do estatuto pessoal - unidade e dispersão (algumas notas a propósito da comemoração dos 35 anos do Código Civil" in Comemorações dos 35 anos do código civil e dos 25 anos da reforma de 1977 (Coimbra: Coimbra Editora - Faculdade de Direito da Universidade de Coimbra, 2006), 559 and 594; Adolfo Miaja de la Muela, "Las normas materiales de Derecho internacional privado", Revista Española de Derecho Internacional XVI, no. 3 (1963): 430; Miguel Amores Conradi and Elisa Torralba Mendiola, "El DIPr ante la globalización: repercusiones y algunas tendencias (en una perspectiva española)", in A Internacionalização do Direito no Novo Século - Studia Iuridica no. 94, ed. Jorge de Figueiredo Dias (Coimbra: Coimbra Editora - Boletim da Faculdade de Direito da Universidade de Coimbra, 2009), 87; Geraldo Ribeiro, "A europeização do direito internacional privado e direito processual internacional: Algumas notas sobre o problema da interpretação do âmbito objectivo dos regulamentos comunitários", Julgar 23 (2014): 268; Andrés Rodríguez Benot, "El criterio de conexión para determinar la ley personal: un renovado debate en derecho internacional privado", Cuadernos de Derecho Transnacional 2, no. 1 (2010): 188.

${ }^{23}$ Cf. Horatia Muir Watt, “The challenge of market integration for European conflicts theory”, 195. Semipublic law aims to mention legal institutes difficult to categorise in the classical dichotomy public law / private law. In fact, the concern for social welfare extended to the rules of private relationships, in cases like labour contracts and lease contracts. On this issue, cf., more extensively, Afonso Patrão, Autonomia Conflitual..., 89.

${ }^{24}$ Horatia Muir Watt, "The challenge of market integration for European conflicts theory", 192. Also, António Ferrer Correia, Direito Internacional... (1997), 45; Veerle van den Eeckhout, The Instrumentalisation of Private International Law: Quo Vadis? - Rethinking the 'Neutrality' of Private International Law in an Era of Globalisation and Europeanisation of Private International Law (Leiden: University of Leiden, 2012), http://ssrn.com/abstract=2338275, 3. 
This is not an unknown circumstance for the European Union, which has been exercising its competence in the field of private international law to fulfil its own policies. In fact, when only States had internal rules on the conflict of laws, "private international rules [were] conceived by competing players in the field of substantive legislation, a field without referee. Since and to the extent that the Community is not a player in this field, it rather acts as referee when legislating in private international law" ${ }^{25}$ Not having powers to adopt substantive legislation, the European competence on private international law is exercised in a more neutral way and is employed as a tool for stimulating European policies - especially the achievement of the basic freedoms, becoming a means for achieving European integration. ${ }^{26}$

In fact, if the promotion of international relations is the genetic intent of private international law and simultaneously the purpose of European integration, the rules on the conflict of laws are a powerful ally accomplishing

\footnotetext{
${ }^{25}$ Cf. Jürgen Basedow, “The communitarisation of private...”, 459.

26 "15 years of European private international law - Achievements, conceptualization and outlook", 181; "Spécificité et coordination du droit international privé communautaire", Travaux du Comité Français de Droit International Privé (2002-2004): 280; Michael Grünberger, “Alles obsolet? - Anerkennungsprinzip vs. klassisches IPR", 103: "Die Auswahl des nunmehr EU-weit einheitlichen Anknüpfungspunkts ist freilich seinerseits wieder Gegenstand einer genuin politischen Entscheidung"; Alegría Borrás, "Le droit...”, 328; Pedro Miguel Asensio, “Integración...”, 425 and 442; Rui Moura Ramos, "O Tribunal de Justiça das Comunidades Europeias e a teoria geral do direito internacional privado. Desenvolvimentos recentes”, in Estudos de Direito Internacional Privado e de Direito Processual Civil Internacional (Coimbra: Coimbra Editora, 2007), 52: "parece indiscutido que o direito internacional privado irá ocupar um lugar de crescente relevância na construção comunitária”; Isabelle Barrière Brousse, “Le Traité...”, 32; Johan Meeusen, "Instrumentalisation of private international law in the European Union: Towards a European conflicts revolution?”, European Journal of Migration and Law 9, no. 3 (2007): 287 and 304; Julio González Campos, "Diversification, spécialisation, flexibilisation et matérialisation des règles de droit international privé”, Recueil des Cours de l'Académie de Droit International 287 (2000): 120 - "ce qui implique, en somme, un processus qui conduit à la 'communautarisation' des systèmes de droit international privé de ceux-ci, au service des objectifs de l'Union européenne”; David Lefranc, "La spécificité des règles de conflit de lois en droit communautaire dérivé (aspects de droit privé)", Revue Critique de Droit International Privé 94, no. 3 (2005): 418; Veerle van den Eeckhout, The Instrumentalisation of Private International Law: Quo Vadis? - Rethinking the 'Neutrality' of Private International Law in an Era of Globalisation and Europeanisation of Private International $L a w, 3$. This is probably one of the reasons justifying the "integração de diversas áreas do direito internacional privado no âmbito material do direito comunitário, assim se manifestando àquela primeira disciplina a força expansiva que sempre tem vindo a ser reconhecida a esta última”. Rui Moura Ramos, O Tribunal de Justiça das Comunidades Europeias e a Teoria..., 39.
} 
the internal market. And that is the reason why writers mention the instrumentalisation of private international law by the European Union. ${ }^{27}$

The simple unification of the rules in the conflict of laws is, of course, a condition to the "proper functioning of the internal market, in order to improve the predictability of the outcome of litigation, certainty as to the law applicable and the free movement of judgments, for the conflict-of-law rules in the Member States to designate the same national law irrespective of the country of the court in which an action is brought" ${ }^{28}$ But the selection of the connecting factor is not innocuous, as it can favour the purpose of European integration. One of the most obvious examples is the progressive substitution, in the European instruments on the conflict of laws, of the connecting factor nationality with habitual residence, encouraging the integration of persons exercising their freedom of movement into the receiving country's community and, thus, favouring the free movement of people. ${ }^{29}$

\footnotetext{
${ }^{27}$ Cf. Erik Jayme, "Il diritto...", 355: "Il diritto internazionale privato serve - sempre secondo le intenzioni del legislatore comunitario - all'integrazione europea"; Luca G. Radicati di Brozolo, "L'influence...", 423; Vincent Heuzé, "De la compétence de la loi du pays d'origine en matière contractuelle ou l'anti-droit européen", 395 - referring the "asservissement du droit international privé aux objectifs du Traité CE”; Johan Meeusen, "Instrumentalisation...", 288: "the resulting transformation of the former could be labelled as instrumentalisation"; Marc Fallon, "Les conflits...", 199: "Les règles communautaires de droit international privé méritent un aperçu de leur contenu sous l'angle de leur contribution à la réalisation du marché intérieur"; Jürgen Basedow, "Der kollisionsrechtliche...", 3: "eine so internationale Materie wie das IPR aus der Natur der Sache einen Beitrag zur Integration leisten könnte”; "Spécificité...", 292; Santiago Álvarez González, "Derecho internacional privado y derecho privado europeo", in Derecho Privado Europeo, ed. Sergio Cámara Lapuente (Madrid: Editorial Colex, 2003), 185: "el DIPr cobra un cierto protagonismo como alternativa a la armonización”; Alex Mills, Towards a Public International Perspective on Private International Law: Variable Geometry and Peer Governance (2012), http://ssrn.com/ abstract=2025616, 9: "Private International Law is part of the process of defining the European legal order and facilitating the efficient functioning of the internal market"; Herbert Kronke, "Connecting factors and internationality in conflict of laws and transnational commercial law", 59: "A regional economic integration organisation such as the European Union may push for a change from nationality to habitual residence with a view to facilitating greater mobility of persons within its economically integrated area"; Giorgio Badiali, "Le droit international privé des Communautés Européennes", Recueil des Cours de l'Académie de Droit International 191 (1985): 22.

${ }^{28}$ Recital 6 of Regulation (EC) 593/2008, on the law applicable to contractual obligations (Rome I) and of Regulation (EC) 864/2007, on the law applicable to non-contractual obligations (Rome II). ${ }^{29}$ Cf. Geraldo Ribeiro, “A europeização...", 268; Ana Luísa Balmori Padesca, "Elección de ley y estatuto personal", in Autonomía de la Voluntad en el Derecho Privado - Estudios en Conmemoración del 150 Aniversario de la Ley del Notariado, ed. Lorenzo Prats Albentosa (Madrid: Consejo General del Notariado - Wolters Kluwer España, 2013), 364; Anatol Dutta, "Succession
} 


\section{Party autonomy: removing obstacles to legal diversity}

The former conclusions - the persistence of legal diversity as an obstacle to the internal market (i) and the instrumentalisation of private international law as a European tool towards the internal market (ii) - drive to a question: is there a transversal policy by the European Union on its instruments on the conflict of laws which would erase the eventual obstacles of legal diversity within private law?

The answer has been obvious, not only to the European Institutions with law-making powers but also to the case-law of the ECJ, which concluded that overriding national rules to basic freedoms, even if allowed by the exceptions of the Treaty, is not an obstacle to the internal market if the parties are free to prevent their application. The possibility of choosing the applicable law (professio iuris) makes legal diversity unproblematic, since economic agents will elect the rules which satisfy its purposes, enhancing international movement. In fact, the freedom to choose the applicable law is a general principle of Private International Law of the European Union, being used in all areas of European intervention. ${ }^{30}$

and wills in the conflict of laws on the eve of europeanisation", Rabels Zeitschrift für ausländisches und internationales Privatrecht 73, no. 3 (2009): 563.

${ }^{30} \mathrm{Cf}$. Jan von Hein, "Of older siblings and distant cousins: The contribution of the Rome II Regulation to the communitarisation of private international law", Rabels Zeitschrift für ausländisches und internationales Privatrecht 73, no. 3 (2009): 465 and 486; Janeen M. Carruthers and Elizabeth B. Crawford, "Variations on a theme of Rome II. Reflections on proposed choice of law rules for non-contractual obligations”, Edinburgh Law Review 65 (2005): 82; Janeen M. Carruthers, "Party autonomy in the legal regulation of adult relationships: What place for party choice in private international law?", International and Comparative Law Quarterly 61 (2012): 888; Javier Carrascosa González, "Règle de conflit et théorie économique", Revue Critique de Droit International Privé 101, no. 3 (2012): 535; "Reglamento sucesorio europeo y actividad notarial", Cuadernos de Derecho Transnacional 6, no. 1 (2014), 22; Andrea Bonomi, "Le choix de la loi applicable à la succession dans la proposition de règlement communautaire", Cursos de Derecho Internacional y Relaciones Internacionales de Vitoria-Gasteiz (2010): 251; Giacomo Biagioni, "Technische internazionalprivatistische fondate sulla volontà delle parti nel diritto dell'Unione Europea" Cuadernos de Derecho Transnacional 2, no. 2 (2010): 16; Paul Lagarde, "Les principes de base du nouveau règlement européen sur les successions", Revue Critique de Droit International Privé 101, no. 4 (2012): 719; Riccardo Luzzatto, "Riflessioni sulla C. D. Comunitarizzazione del diritto internazionale privato", in Nuovi Strumenti del Diritto Internazionale Privato - Liber Fausto Pocar, ed. Gabriella Venturini and Stefania Bariatti (Milano: Giuffrè Editore, 2009), 625; Maarja Torga, "Party autonomy of the spouses under the Rome III Regulation in Estonia - can private international law change substantive law?", Nederlands Internationaal Privaatrecht 4 (2012): 547; Ornella Feraci, "Lautonomia della volontà nel diritto internazionale privato dell'Unione Europea", Rivista di Diritto Internazionale 96, no. 2 (2013): 424 and 430; Tito Ballarino, "Il nuovo regolamento europeo sulle successioni", Rivista di Diritto Internazionale XCVI, no. 4: 1123; Pilar Blanco-Morales Limones, "La autonomía 
The reasons for allowing the parties to choose the applicable law in almost all of European Instruments on the conflict of laws ${ }^{31}$ are not merely in the merits of party autonomy (enhancement of private self-determination; certainty, predictability and easiness of ascertainment of the applicable law; creation of regulatory competition among several States), although all reasons are coherent with the regime of basic freedoms..$^{32}$ Instead, the elimination of obstacles to the freedom of movement is a key purpose of the European Union when establishing such connecting factor. ${ }^{33}$

de la voluntad en las relaciones plurilocalizadas. Autonomía de la voluntad. Elección de ley aplicable: Consentimiento y forma de los actos", in Autonomía de la Voluntad en el Derecho Privado - Estudios en Conmemoración del 150 Aniversario de la Ley del Notariado, ed. Lorenzo Prats Albentosa (Madrid: Consejo General del Notariado - Wolters Kluwer España, 2013), 10; Gerald Goldstein and Horatia Muir Watt, "La méthode de la reconnaissance à lueur de la Convention de Munich du 5 septembre 2007 sur la reconnaissance des partenariats enregistrés” Journal du Droit International 137, no. 4 (2010), 1111; Andrea Bonomi, "La Convention de la Haye sur les titres, une nouvelle avancée de l'autonomie des parties en droit international privé", in La Loi Applicable aux Titres Intermédiés: La Convention de la Haye du 5 Juillet 2006 - Une Opportunité Pour la Place Financière Suisse?, ed. Andrea Bonomi, Eleanor Cashin Ritaine, and Bart Volders (Genebra: Schulthess, 2006), 11.

${ }^{31}$ Cf. article 3 of Regulation (EC) 593/2008, on the law applicable to contractual obligations (Rome I); article 14 of Regulation (EC) 864/2007, on the law applicable to non-contractual obligations (Rome II); article 15 of Regulation (EC) 4/2009, on jurisdiction, applicable law, recognition and enforcement of decisions and cooperation in matters relating to maintenance obligations, which endorses the rules of Hague Protocol of 23 November 2007 on the law applicable to maintenance obligations; article 5 of Regulation (EU) 1259/2010, on the law applicable to divorce and legal separation; article 22 of Regulation (EU) 650/2012, on jurisdiction, applicable law, recognition and enforcement of decisions and acceptance and enforcement of authentic instruments in matters of succession; article 22 of Regulation (EU) 1103/2016, on jurisdiction, applicable law and the recognition and enforcement of decisions in matters of matrimonial property regimes; article 22 of Regulation (EU) 1104/2016, on jurisdiction, applicable law and the recognition and enforcement of decisions in matters of the property consequences of registered partnerships.

${ }^{32}$ On the reasons of establishing party autonomy in the conflict of laws - and on the extension of such connecting factor to new fields -, cf. Afonso Patrão, Autonomia Conflitual..., 535.

${ }^{33}$ Cf. Jürgen Basedow, "Der kollisionsrechtliche...", 27: Die Zulassung der Rechtswahl bedeutet nichts anderes, als daß das nationale Kollisionsrechts, gleich ob vereinheitlich oder autonom, gerade keine staatlichen Beschränkungen für den grenzüberschreitenden Wirtschaftsverkehr innerhalb der Gemeinschaft errichtet, die am Maßstab der Art. 30 und 59 EGV gemessen werden könnten"; António Frada de Sousa, A Europeização..., 844: "A intervenção do legislador europeu no domínio dos conflitos de leis em matéria civil e comercial, após a entrada em vigor do Tratado de Amesterdão, levou à adopção de instrumentos de DIP derivado europeu onde pontifica o princípio da autonomia da vontade como critério base de determinação da lei aplicável"; Erik Jayme, "Party autonomy in international family and succession law: New tendencies", Yearbook of Private International Law 11 (2009): 3 "in Europe, introducing party autonomy in international family law is motivated by the needs of integration in the European Union, rather than by ideas of selfdetermination of the person"; Anna Gardella, "Articulo 3. - Commentario al Regolamento (CE) 
n. 593/2008 del Parlamento europeo e del Consiglio del 17 giugno 2008 sulla legge applicabile alle obbligazioni contrattuali ('Roma I'), Francesco Salerno, Pietro Franzina (eds.)", Le Nuove Leggi Civili Commentate 3/4 (2009): 614 "la volontà private è spesso considerate come il criterio di collegamento più adatto a realizzare pienamente le libertà fondamentali sancite dal Tratt. CE"; Janeen M. Carruthers, "Party...", 889; Axel Flessner, "Security interests in receivables - A European perspective", in The Future of Secured Credit in Europe, ed. Horst Eidenmüller and Eva-Maria Kieninger (Munique: De Gruyter Recht, 2008), 346: "For the Community, where it is making conflict of law rules for the internal market, party autonomy is mandatory under the basic freedoms"; Paul Lagarde, "Les principes...", 697: "La combinaison des principes d'unité et d'autonomie devrait donc contribuer à l'objectif de suppression des entraves à la libre circulation des personnes"; Alfonso Luis Calvo Caravaca and Javier Carrascosa González, "El Convenio de Roma sobre la Ley Aplicable a las Obligaciones Contractuales de 19 de Junio de 1980", in Contratos Internacionales, ed. Alfonso Luis Calvo Caravaca, Luis Fernández de la Gándara, and Pilar Blanco-Morales Limones (Madrid: Editorial Tecnos, 1997), 74: "al permitir la elección de la ley más conveniente a los contratantes, se potencia la contratación internacional, y en última instancia, el intercambio económico y la circulación internacional de la riqueza. Dicha promoción de la contratación internacional llevada a cabo por el DIPr. Se basa en una idea de libre competencia entre las leyes estaduales"; Dário Moura Vicente, "Perspectivas da harmonização e unificação internacional do direito privado num época de globalização da economia", in Estudos em Honra do Professor Doutor José de Oliveira Ascensão, ed. António Menezes Cordeiro, Pedro Pais de Vasconcelos, and Paula Costa e Silva (Coimbra: Almedina, 2008), 1669; Anabela de Sousa Gonçalves, Da Responsabilidade Extracontratual em Direito Internacional Privado (Coimbra: Almedina, 2013), 293; Marc Fallon, "Les conflits...", 77 and 145; Luca G. Radicati di Brozolo, "L'influence...", 411; Oliver Remien, "European private international law, the European Community and its emerging area of freedom, security and justice", Common Market Law Review 38, no. 1 (2001), 83; Horatia Muir Watt, "The challenge of market integration for European conflicts theory", 198; Fernanda Muraro Bonatto, "O Regulamento no. 1259/2010 da União Europeia: breves considerações sobre a lei aplicável em matéria de divórcio e separação judicial e a autonomia das partes na escolha da lei aplicável", Revista Electrónica de Direito 2 (2013), www.cije.up.pt/revistared, 20; Mónica Guzmán Zapater, "La ley nacional e intervención notarial en sucesiones", in Autonomía de la Voluntad en el Derecho Privado - Estudios en Conmemoración del 150 Aniversario de la Ley del Notariado, ed. Lorenzo Prats Albentosa (Madrid: Consejo General del Notariado - Wolters Kluwer España, 2013), 305306; Pietro Franzina, "L'autonomia della volontà nel regolamento sui conflitti di leggi in materia di separazione e divorzio", Rivista di Diritto Internazionale XCIV, no. 2 (2011), 490; Beatriz Añoveros Terradas, "La autonomía de la voluntad como principio rector de las normas de derecho internacional privado comunitario de la familia", in Entre Bruselas y la Haya: Estudios sobre la Unificación Internacional y Regional del Derecho Internacional Privado - Liber Amicorum Alegría Borrás, ed. Joaquin Forner Delaygua, Cristina González Beilfuss, and Ramón Viñas Farré (Madrid: Marcial Pons, 2013), 126; Beatriz Campuzano Díaz, "Uniform conflict of law rules on divorce and legal separation via enhanced cooperation", in Latest Developments in EU Private International Law, ed. Beatriz Campuzano Díaz, et al. (Cambridge: Intersentia, 2011), 41; Stefan Leible, "Parteiautonomie im IPR - Allgemeines Anknüpfungsprinzip oder Verlegenheitslösung?", in Festschrift für Erik Jayme (München: Sellier - European Law Publishers, 2004), 501; Andrés Rodríguez Benot, "El criterio...", 202; Heinz-Peter Mansel, "Parteiautonomie, Rechtsgeschäftslehre der Rechtswahl und allgemeinen Teil des europäischen Kollisionsrechts", in Brauchen wir eine Rom 0-Verordnung?, ed. Stefan Leible and Hannes Unberath (Jena: Jenaer Wissenschaftliche Verlagsgesellschaft, 2013), 263. 
On the one hand, if parties can elect the legal rules of international contracts, non-contractual liability, maintenance obligations, matrimonial regimes, divorce and inheritance, the fact that Member States adopt different substantive rules is not as barrier to basic freedoms, since individuals may adjust their conduct to the legal system of their choice. Thus, when dealing with an international situation, it is possible to ascertain the specific legal system the parties know and in which they trust, eliminating doubts on the legal regime of such transactions; if there is more flexibility and legal certainty establishing the legal status of individuals - because the parties self-determine the applicable rules regardless of the Member State where they live - citizens' mobility is increased, by wiping out one of the obstacles to movement. ${ }^{34}$

On the other hand, free movement of people must grant a stability of the citizens' legal status, notwithstanding the alteration of domicile. Their matrimonial regime, their organisation of succession in advance, their name or the validity of contracts concluded before must not be in jeopardy as a consequence of the exercise of a basic freedom. To this aim, professio iuris is a perfect connecting factor: if parties are free to decide, in every Member State, the applicable law to their status, their movement will not affect it, facilitating the management of their lives regardless of the Member State where they choose to reside. ${ }^{35}$

Finally, party autonomy may avoid the application of overriding national rules which could refrain European freedoms - even if the restriction was allowed by the Treaty -, as stressed out by the European Court of Justice. In fact, it expressly declared party autonomy would wipe away barriers on the freedom of movement possibly caused by legal diversity, implicitly advising the use of such connecting factor in order to fulfil the Treaty's objectives. In Judgment Alsthom Atlantique, when analysing the

\footnotetext{
${ }^{34}$ This is stressed not only by most writers - cf. previous footnote - but by the European Regulations. Cf. Recital 15 of Regulation (EU) 1259/2010, on the law applicable to divorce and legal separation: "Increasing the mobility of citizens calls for more flexibility and greater legal certainty. In order to achieve that objective, this Regulation should enhance the parties' autonomy in the areas of divorce and legal separation by giving them a limited possibility to choose the law applicable to their divorce or legal separation".

${ }^{35}$ This is stressed not only by most writers - cf. footnote 32 - but by the European Regulations. Cf. Recital 45 of Regulation (EU) 1103/2016, on jurisdiction, applicable law and the recognition and enforcement of decisions in matters of matrimonial property regimes: "To facilitate to spouses the management of their property, this Regulation should authorise them to choose the law applicable to their matrimonial property regime, regardless of the nature or location of the property, among the laws with which they have close links".
} 
compatibility of the freedom of movement of goods with French rules on the seller's liability on defective goods, the ECJ declares "the parties to an international contract of sale are generally free to determine the law applicable to their contractual relations and can thus avoid being subject to French law". Hence, because the parties were free to choose another applicable law, although the national rules would be allowed by European law, the barrier would not be mandatorily applied to parties. ${ }^{36}$

These considerations point out a conclusion: the European Union is embracing party autonomy as a complement to mutual recognition in areas where it would not be enough to wipe out the difficulties inherent to legal diversity - especially within private law. Therefore, this fact must be recognised as one of the tools used by the Institutions in order to accomplish the internal market.

\footnotetext{
${ }^{36}$ Judgment of 24 January 1991, Alsthom Atlantique SA v. Compagnie de construction mécanique Sulzer SA, C-339/89, EU:C:1991:28, \$15. Acknowledging the same interpretation, cf. Anna Gardella, "Articulo 3....", 614; Peter von Wilmowsky, "EG-Vertrag...", 6; Horatia Muir Watt, "Aspects économiques du droit international privé", Recueil des Cours de l'Académie de Droit International 307 (2004), 213: "L'entrave à la prestation transfrontière de services: éflexions sur l'impact des libertés économiques sur le droit international privé des États membres”, in Études Offertes à Jacques Béguin - Droit et Actualité (Paris: LITEC, 2005), 562; Julio González Campos, "La Cour de Justice des Communautés Européennes et le non-droit international privé", in Festschrift für Erik Jayme (München: Sellier - European Law Publishers, 2004), 268; Ben Smulders and Paul Glazener, "Harmonization in the field of insurance law through the Introduction of Community rules of conflict", Common Market Law Review 29, no. 4 (1992), 777; Walter van Gerven and Jan Wouters, "Free movement of financial services and the European Contracts Convention", in EC Financial Market Regulation and Company Law, ed. Mads Andenas and Stephen Kenyon-Slade (Londres: Sweet \& Maxwell, 1993), 67; Matteo Ortino, "The role...", 321; Ornella Feraci, "L'autonomia...", 431. Said in a different way: the ECJ declared party autonomy makes legal diversity unproblematic, since the parties may elect the applicable law. Cf. Dário Moura Vicente, "Perspectivas da harmonização e unificação internacional do direito privado num época de globalização da economia", 1669; "Um Código Civil para a Europa? Algumas reflexões", in Direito Internacional Privado - Ensaios (Coimbra: Almedina, 2002), 10; Stefan Grundmann, "The structure of European contract law", European Review of Private Law 9, no. 4 (2001): 514; Horatia Muir Watt, "The challenge of market integration for European conflicts theory", 199; Luca G. Radicati di Brozolo, "L'influence...", 411413; Marc Fallon, "Les conflits...", 77 and 145; Peter von Wilmowsky, "EG-Vertrag...", 6; Oliver Remien, "European...", 83; Ben Smulders and Paul Glazener, "Harmonization in the field of insurance law through the introduction of Community rules of conflict", Common Market Law Review 29, no. 4 (1992), 777; Javier Carrascosa González, "La autonomía de la voluntad conflictual y la mano invisible en la contratación internacional”, Diario La ley 7874 (2012); Hendrik Verhagen and Sanne van Dongen, "Cross-border assignments under Rome I", Journal of Private International Law 6, no. 1 (2010), 18; Arthur Hartkamp, "Modernisation and harmonisation of contract law: Objectives, methods and scope”, Uniform Law Review 8, no. 1/2 (2003): 82.
} 


\section{Concluding remarks and further perspectives}

The embracement, by the European Union, of professio iuris as a mechanism favouring the internal market will probably not stop. In fact, allying the possibility of choice of law with the effort for harmonisation and the principle of mutual recognition aids the removal of obstacles to the European freedoms caused by legal diversity.

That is why writers predict its extension to new areas, such as property law - namely to securities on moveable property. In fact, the movement of assets may jeopardise the effectiveness of the creditor's security right because of the movement of goods, which is supposed to be guaranteed by the Treaty. ${ }^{37}$ This problem could be minimised by extending professio iuris

\footnotetext{
${ }^{37}$ In fact, when a moveable asset is taken to a different Member State, the traditional rule on the conflict of laws - lex rei sitae - makes applicable to securities on that good a different regime, which may establish the invalidity of the rights of the creditor. Therefore, the classical connecting factor may be an obstacle to the freedom of movements of assets. In consequence, some literature sustains European law on the movement of goods is incompatible with the invalidity of security rights as a consequence of the movement of assets - Christiane Wendehorst, "Sachenrecht", in Münchener Kommentar zum bürgerlichen Gesetzbuch, ed. Roland Rixecker and Franz Jürgen Säcker (München: Beck, 2010), 220 and 271; Wulf-Henning Roth, "Die Freiheiten des EG-Vertrages und das nationale Privatrecht", Zeitschrift für europäisches Privatrecht 1 (1994): 24; Anne Röthel, "Internationales...", 1028; Bram Akkermans, "Property law and internal market", 206: "When, because of the application of lex rei sitae, a certain national system of property law applies, and a property right created under the law is not recognised by another Member State, this will affect the way in which trade between these Member States is conducted"; Bram Akkermans and Eveline Ramaekers, "Free movement of goods and property law", European Law Journal 19, no. 2 (2013): 242; Eveline Ramaekers, European..., 7 and 53; Axel Flessner, "Security interests in receivables - A European perspective", 342: "After Centros, Überseering and Inspire Art, it is no longer allowed to nullify a corporation switching its business into another member state, nor to force it into an unwanted new legal form. Why should it be different when property is moved the same way?; Wulf-Henning Roth, "Secured credit and the internal market: The fundamental freedoms and the EU's mandate for legislation", ibid., 41-42 and 59; "Die Freiheiten...", 25; Dominique Bureau and Horatia Muir Watt, "Droit international privé", in Partie Générale (Paris: Presses Universitaires de France, 2010), 454; Christoph Schmid, "Options under EU law for the implementation of a eurohypothec", 63: "such a transposition is mandated by the basic freedoms. Indeed, the restriction of the freedom of capital (which encompasses the right of a debtor to secure dept by mortgage) through the wholesale non-recognition of a foreign real property right is not proportional if the right could have been exercised, after the good has crossed the border, in the form of a similar national-security right"; Horst Eidenmüller, "Secured creditors in insolvency proceedings", in The Future of Secured Credit in Europe, ed. Horst Eidenmüller and Eva-Maria Kieninger (Munique: De Gruyter Recht, 2008), 282; Anne Röthel, “Internationales...”, 1031; Jürgen Basedow, "Der kollisionsrechtliche...”, 41; Anna Gardella, Le Garanzie finanziarie nel Diritto Internazionale Privato (Milão: Giuffrè Editore, 2007), 53; Andrea Bonomi, "La nécessité d'harmonisation du droit des garanties réelles mobilières", in L’Européanisation du Droit Privé: Vers un Code Civil Européen?, ed. Franz Werro (Fribourg: Editions Universitaires Fribourg Suisse, 1998), 514, and "La riserva della
} 
to this field, ${ }^{38}$ removing the obstacle generated by the existence of different laws within the internal market. Or even, as sustained elsewhere, ${ }^{39}$ to mortgages on immoveable property, since legal diversity in property rights makes the acceptance of a mortgage in a foreign Member State unattractive, distorting the freedom of movement of capital.

The fact that these areas are strongly ruled, in all Member States, by norms on the conflict of laws with stable connecting factors shall not be a hurdle: one of the features of private international law is its versatility, because its methods - and the election of its connecting factors - follow the political and economic circumstances. Therefore, rules on the conflict of laws which were universal have been replaced by new criteria, fulfilling different purposes - and the European Union has been impressively important in such tendency. ${ }^{40}$

proprietà nel diritto internazionale privato", Rivista di Diritto Internazionale Privato e Processuale 4 (1992), 778; Friedrich K. Juenger, "Private international law or international private law?", King's College Law Journal 5 (1994-1995): 5; Marc Fallon, Patrick Kinsch, and Christian Kohler, "Le droit international privé européen en construction - building european private international law", in Vingt Ans de Travaux du GEDIP - Twenty Years' Work by GEDIP (Cambridge: Intersentia, 2011), 91; Marc Fallon, "Groupe européen de droit international privé - Quatrième réunion, Barcelone, 29 septembre - ler octobre 1994”, Revue Belge de Droit International XXVII, no. 2 (1994), 720.

${ }^{38}$ Cf. Helène Gaudemet-Tallon, "Comentário ao Acórdão da Cour de Cassation de 8 de Julho de 1969 (Société DIAC)", La Semaine Juridique - Edition Générale 1970-II (1970), chapters II-C and III; Hans Stoll, "Rechtskollisionen beim Gebietswechsel beweglicher Sachen", Rabels Zeitschrift für ausländisches und internationales Privatrecht 38 (1974), 452; "Zur gesetzlichen Regelung des internationalen Sachenrechts in Art. 43-46 EGBGB", IPRax - Praxis des Internationalen Privat und Verfahrensrechts 4 (2000), 264-265; Thomas Pfeiffer, "Der Stand des internationalen Sachenrechts nach seiner Kodification", ibid., 20, 273; Ulrich Drobnig, "Eigentumsvorbehalte bei Importlieferungen nach Deutschland", Rabels Zeitschrift für ausländisches und internationales Privatrecht 32 (1968), 460; Anna Gardella, Le Garanzie..., 43; Michael Bridge, "English conflicts rules for transfers of movables: A contract-based approach?", in Cross-Border Security and Insolvency, ed. Michael Bridge and Robert Stevens (Oxford: Oxford University Press, 2004), 137; Pierre Mayer and Vincent Heuzé, Droit International Privé (Paris: Montchrestien, 2010), 498; Georges Khairallah, Les Sûretés Mobilières en Droit International Privé, (Paris: Economica, 1984), 220; Rolf Weber, "Parteiautonomie im internationalen Sachenrecht?", Rabels Zeitschrift für ausländisches und internationales Privatrecht 44 (1980): 521.; Isabelle Juvet, Des Sûretés Mobilières Conventionnelles en Droit International Privé (Bern: Peter Lang, 1991), 83; horst eidenmüller, "secured creditors in insolvecy procedings", 282; Axel Flessner, "Security interests in receivables - A European Perspective", ibid., 346; Anne Röthel, "Internationales...", 1034; Arnaud Nuyts, "Le droit de rétention en droit international privé: Quelques observations sur le rôle de la loi de l'obligation, de la loi réelle, et de la loi du lieu d'exécution", Revue Générale de Drot Civil Belge 6, no. 1 (1992): 45.

${ }^{39}$ Afonso Patrão, Autonomia Conflitual..., 567.

${ }^{40}$ On the responsibility of European Union replacing the classical connecting factors, cf. JeanFrançois Gojon, "Loi réelle et loi de la créance dans le crédit hypothécaire: Un concours encore 
In conclusion: no doubts existing on the ability of professio iuris as a tool of promotion of the internal market - overcoming the barriers created by legal diversity, even when the application of restricting national regulation would be allowed by the Treaty -, it shall be recognised as one important device of European Institutions on this field. This recognition will probably have practical effects in the coming European instruments, possibly allowing the choice of law in areas like the personal status of individuals or property law. The purpose of achieving a proper functioning of the internal market makes predictable the persistence of choice of law as tool of European Union in the near future.

\section{Bibliography}

Aguilar Navarro, M. "Algunos supuestos politicos del Derecho Internacional Privado". Revista Española de Derecho Internacional XIII, no. 1-2-3 (1960): 45-82.

Akkermans, Bram. "Property law and internal market". In The Future of European Property Law, edited by Sjef van Erp, Arthur Salomons and Bram Akkermans, 199246. Munique: Sellier European Law Publishers, 2012.

Akkermans, Bram, and Ramaekers, Eveline. "Free movement of goods and property law”. European Law Journal 19, no. 2 (2013): 237-266.

Alfaro Águila-Real, Jesús. "La unificación del derecho privado en la Unión Europea: Perspectiva”. In Derecho Privado Europeo, edited by Sergio Cámara Lapuente, 107127. Madrid: Editorial Colex, 2003.

Álvarez González, Santiago. "Derecho internacional privado y derecho privado europeo". In Derecho Privado Europeo, edited by Sergio Cámara Lapuente, 157-190. Madrid: Editorial Colex, 2003.

Amores Conradi, Miguel, and Torralba Mendiola, Elisa. "El DIPr ante la globalización: Repercusiones y algunas tendencias (en una perspectiva española)". In $A$ Internacionalização do Direito no Novo Século - Studia Iuridica no. 94, edited by Jorge de Figueiredo Dias, 73-126. Coimbra: Coimbra Editora - Boletim da Faculdade de Direito da Universidade de Coimbra, 2009.

Añoveros Terradas, Beatriz. "La autonomía de la voluntad como principio rector de las normas de derecho internacional privado comunitario de la familia”. In Entre Bruselas y la Haya: Estudios Sobre la Unificación Internacional y Regional del Derecho Internacional Privado - Liber Amicorum Alegría Borrás, edited by Joaquin Forner

incertain", in Mélanges en l'Honneur de Mariel Revillard - Liber Amicorum (Paris: Defrénois, 2007), 169 ("le droit international privé d'origine communautaire tend à élargir sa place et à constituer un champ d'expérimentation et d'accélération des solutions classiques qui prévalaient jusqu'à son essor"). 
Delaygua, Cristina González Beilfuss and Ramón Viñas Farré, 119-131. Madrid: Marcial Pons, 2013.

Arenas García, Rafael. "Abolition of exequatur: Problems and solutions - Mutual recognition, mutual trust and recognition of foreign judgements: Too many words in the sea”. Yearbook of Private International Law 12 (2010): 351-375.

"Sombras y luces en la jurisprudencia del Tribunal de Justicia de la Unión Europea en materia de DIPr de sociedades". In Nuevas Fronteras del Derecho de la Unión Europea - Liber Amicorum José Luis Iglesias Buhigues, edited by Carlos Esplugues Mota and Guillermo Palao Moreno, 739-759. Valencia: Tirant lo Blanch, 2012.

Audit, Bernard. "Le droit international privé à la fin du XXe siècle: Progrès ou recul". Revue Internationale de Droit Comparé 50, no. 2 (1998): 421-488.

Audit, Bernard, and d'Avout, Louis. Droit International Privé. Paris: Economica, 2010.

Audit, Mathias. "Régulation du marché intérieur et libre circulation de lois". Journal du Droit International 4 (2006): 1333-1363.

Badiali, Giorgio. "Le droit international privé des Communautés Européennes". Recueil des Cours de l'Académie de Droit International 191 (1985): 9-182.

Ballarino, Tito. "Il nuovo regolamento europeo sulle successioni". Rivista di Diritto Internazionale XCVI, no. 4 (2013): 1116-1645.

Baratta, Roberto. "Problematic elements of an implicit rule providing for mutual recognition of personal and family status in the EC". IPRax - Praxis des Internationalen Privat und Verfahrensrechts, no. 1/2007 (2007): 4-11.

Bariatti, Stefania. "Reconnaissance et droit de l'Union Européenne". In La Reconnaissance des Situations en Droit International Privé, edited by Paul Lagarde, 61-66. Paris: Pedone, 2013.

Barnard, Catherine. The Substantive Law of the EU - The Four Freedoms. Oxford: Oxford University Press, 2004.

Barnard, Catherine, and Deakin, Simon. "Market access and regulatory competition". Jean Monnet Working Papers, no. 9/01 (2001): 1-40.

Basedow, Jürgen. "15 years of European private international law - Achievements, conceptualization and outlook". In Entre Bruselas y la Haya: Estudios Sobre la Unificación Internacional y Regional del Derecho Internacional Privado - Liber Amicorum Alegría Borrás, edited by Joaquin Forner Delaygua, Cristina González Beilfuss and Ramón Viñas Farré, 175-183. Madrid: Marcial Pons, 2013.

"Der kollisionsrechtliche Gehalt der Produktfreiheiten im europäischen Binnenmarkt: Favor offerentis". Rabels Zeitschrift für ausländisches und internationales Privatrecht 59, no. 1 (1995): 1-55.

"EC Conflict of Laws - A matter of coordination". In Seminário Internacional sobre a Comunitarização do Direito Internacional Privado - Direito de Conflitos, 
Competência Internacional e Reconhecimento de Sentenças Estrangeiras, edited by Luís de Lima Pinheiro, 17-30. Coimbra: Almedina, 2005.

"Spécificité et coordination du droit international privé communautaire". Travaux du Comité Français de Droit International Privé (2002-2004): 275-305.

. "The communitarisation of private international law". Rabels Zeitschrift für ausländisches und internationales Privatrecht 73, no. 3 (2009): 455-460.

Batiffol, Henri. Aspects Philosophiques du Droit International Privé. Paris: Dalloz, 1956. "De l'usage des principes en droit international privé". In Estudos em Homenagem ao Prof. Doutor A. Ferrer-Correia, 103-119. Coimbra: Faculdade de Direito da Universidade de Coimbra, 1986.

"L'état du droit international privé en France et dans l'Europe continental de l'Ouest”. In Choix d'Articles. Rassemblés par Ses Amis, 11-31. Paris: LGDJ, 1976.

Biagioni, Giacomo. "Technische internazionalprivatistische fondate sulla volontà delle parti nel diritto dell'Unione Europea”. Cuadernos de Derecho Transnacional 2, no. 2 (2010): 15-34.

Blanco-Morales Limones, Pilar. "La autonomía de la voluntad en las relaciones plurilocalizadas. Autonomía de la voluntad. Elección de ley aplicable: Consentimiento y forma de los actos". In Autonomía de la Voluntad en el Derecho Privado - Estudios en Conmemoración del 150 Aniversario de la Ley del Notariado, edited by Lorenzo Prats Albentosa, 1-166. Madrid: Consejo General del Notariado - Wolters Kluwer España, 2013.

Bonatto, Fernanda Muraro. “O Regulamento no. 1259/2010 da União Europeia: Breves considerações sobre a lei aplicável em matéria de divórcio e separação judicial e a autonomia das partes na escolha da lei aplicável”. Revista Electrónica de Direito 2 (2013): 2-27. http://www.cije.up.pt/revistared.

Bonomi, Andrea. "La Convention de la Haye sur les titres, une nouvelle avancée de l'autonomie des parties en droit international privé". In La Loi Applicable aux Titres Intermédiés: La Convention de la Haye du 5 Juillet 2006 - Une Opportunité Pour la Place Financière Suisse?, edited by Andrea Bonomi, Eleanor Cashin Ritaine and Bart Volders, 9-13. Genebra: Schulthess, 2006.

"La nécessité d'harmonisation du droit des garanties réelles mobilières". In L'Européanisation du Droit Privé: Vers un Code Civil Européen?, edited by Franz Werro, 497-515. Fribourg: Éditions Universitaires Fribourg Suisse, 1998.

"La riserva della proprietà nel diritto internazionale privato". Rivista di Diritto Internazionale Privato e Processuale 4 (1992): 777-818.

"Le choix de la loi applicable à la succession dans la proposition de règlement communautaire". Cursos de Derecho Internacional y Relaciones Internacionales de Vitoria-Gasteiz (2010): 243-271. 
"Le droit international privé entre régionalisme et universalisme". Revue Suisse de Droit International et Européen 16, no. 3 (2006): 295-309.

Borrás, Alegría. "Le droit international privé communautaire: réalités, problèmes et perspectives d'avenir". Recueil des Cours de l'Académie de Droit International, 317 (2005): 313-536.

Bouza Vidal, Nuria. "Modalidades de unificación y armonización de legislaciones en la Comunidad Económica Europea". In Tratado de Derecho Comunitario Europeo, edited by Eduardo García de Enterría, Julio González Campos and Santiago Muñoz Machado, 551-570. Madrid: Editorial Civitas, 1986.

Bridge, Michael. "English conflicts rules for transfers of movables: A contract-based approach?”. In Cross-Border Security and Insolvency, edited by Michael Bridge and Robert Stevens, 123-143. Oxford: Oxford University Press, 2004.

Brito, Maria Helena. "O Regulamento (CE) no. 2201/2003, do Conselho, de 27 de Novembro de 2003, relativo à competência, ao reconhecimento e à execução de decisões em matéria matrimonial e em matéria de responsabilidade parental". In Estudos em Memória do Professor Doutor António Marques dos Santos, edited by Luís de Lima Pinheiro, Dário Moura Vicente and Jorge Miranda, 305-356. Coimbra: Almedina, 2005.

Brousse, Isabelle Barrière. "Le Traité de Lisbonne et le droit international privé". Journal du Droit International 1 (2010): 3-34.

Brouwer, Onno. "Free movement of foodstuffs and quality requirements: Has the Commission got it wrong?”. Common Market Law Review 25, no. 2 (1988): 237-262.

Brozolo, Luca G. Radicati di. "L'influence sur les conflits de lois des principes de droit communautaire en matière de liberté de circulation". Revue Critique de Droit International Privé 82, no. 3 (1993): 401-424.

"Libre circulation dans la CE et règles de conflit". In L'Européanisation du Droit International Privé, edited by Paul Lagarde and Bernd von Hoffmann, 87-103. Köln: Bundesanzeiger, 1996.

Bureau, Dominique, and Muir Watt, Horatia. "Droit international privé". In Partie Générale. Paris: Presses Universitaires de France, 2010.

Calvo Caravaca, Alfonso Luis, and Carrascosa González, Javier. Derecho Internacional Privado. Granada: Ed. Comares, 2011.

"El Convenio de Roma sobre la ley aplicable a las obligaciones contractuales de 19 de Junio de 1980". In Contratos Internacionales, edited by Alfonso Luis Calvo Caravaca, Luis Fernández de la Gándara and Pilar Blanco-Morales Limones, 41-137. Madrid: Editorial Tecnos, 1997.

Cámara Lapuente, Sergio. "Un derecho privado o un código civil para Europa: planteamiento, nudo y (esquivo) desenlace". In Derecho Privado Europeo, edited by Sergio Cámara Lapuente, 47-106. Madrid: Editorial Colex, 2003. 
Campos, Isabel Menéres. "O direito português da hipoteca". Boletim da Faculdade de Direito da Universidade de Coimbra LXXXV (2009): 725-742.

Campuzano Díaz, Beatriz. "Uniform conflict of law rules on divorce and legal separation via enhanced cooperation". In Latest Developments in EU Private International Law, edited by Beatriz Campuzano Díaz, Marcin Czepelak, Andrés Rodríguez Benot and Ángeles Rodríguez Vázquez, 23-48. Cambridge: Intersentia, 2011.

Carrascosa González, Javier. "La autonomía de la voluntad conflictual y la mano invisible en la contratación internacional”. Diario La Ley 7847 (2012).

"La Autonomía de la voluntad en la contratación internacional". In Autonomía de la Voluntad en el Derecho Privado - Estudios en Conmemoración del 150 Aniversario de la Ley del Notariado, edited by Lorenzo Prats Albentosa, 603-766. Madrid: Consejo General del Notariado - Wolters Kluwer España, 2013.

"Reglamento sucesorio europeo y actividad notarial". Cuadernos de Derecho Transnacional 6, no. 1 (2014): 5-44.

"Règle de conflit et théorie économique". Revue Critique de Droit International Privé 101, no. 3 (2012): 521-538.

Carruthers, Janeen M. "Party autonomy in the legal regulation of adult relationships: What place for party choice in private international law?". International and Comparative Law Quarterly 61 (2012): 881-913.

Carruthers, Janeen M., and Crawford, Elizabeth B. "Variations on a theme of Rome II. Reflections on proposed choice of law rules for non-contractual obligations". Edinburgh Law Review 65 (2005): 65-97 and 238-266.

Collaço, Isabel de Magalhães. "Os reflexos do movimento de integração económica no direito privado e no direito internacional privado”. In Da Execução das Decisões Arbitrais e Judiciais em Direito Internacional: Noveno Congreso, Lisboa, 2-11 de Novembro de 1972, 1-17. Madrid: Secretaría General, 1972.

Correia, António Ferrer. Direito Internacional Privado - Alguns Problemas. Coimbra: Almedina, 1997.

Costa, Mário Júlio Almeida. "Alienação fiduciária em garantia e aquisição de casa própria”. Direito e Justiça - Revista da Faculdade de Ciências Humanas da Universidade Católica Portuguesa I, no. 1 (1980): 41-57.

Crabit, E. "La directive sur le commerce électronique. Le project 'mediterrané”. Revue de Droit de l'Union Européenne, no. 4/2000 (2000): 749-833.

Avout, Louis d'. "Comentário ao Acórdão do Tribunal de Justiça de 14 de Outubro de 2008 Grunkin e Paul, proc. C-353/06”. Journal du Droit International 1 (2009): 203-216.

Dakolias, Maria. "The Second Banking Directive: The issue of reciprocity". Legal Issues of European Integration 18, no. 2 (1991): 69-100. 
Domínguez Luelmo, Andrés. "Derechos de garantía sobre bienes muebles". In Derecho Privado Europeo, edited by Sergio Cámara Lapuente, 967-985. Madrid: Editorial Colex, 2003.

Drewics-Tulodzieca, Agnieszka. "Foreword". In Basic Guidelines for a Eurohypothec - Outcome of the Eurohypothec Workshop November 2004/April 2005, edited by Agnieszka Drewics-Tulodzieca, 3-4. Warsaw: Mortgage Credit Foundation, 2005.

Drobnig, Ulrich. "Eigentumsvorbehalte bei Importlieferungen nach Deutschland". Rabels Zeitschrift für ausländisches und internationales Privatrecht 32 (1968): 450-472.

"Scope and general rules of a European civil code". European Review of Private Law 5, no. 4 (1997): 489-496.

"The law governing credit security". In The Private Law Systems in the EU: Discrimination on Grounds of Nationality and the Need for a European Civil Code, edited by Parlamento Europeu - Directorate General for Research, 57-82. Brussels, 2000 .

"Unified rules on proprietary security - in the world and in Europe". Boletim da Faculdade de Direito da Universidade de Coimbra LXXXV (2009): 667-678.

Dutta, Anatol. "Succession and wills in the conflict of laws on the eve of Europeanisation". Rabels Zeitschrift für ausländisches und internationales Privatrecht 73, no. 3 (2009): 547-606.

Eidenmüller, Horst. "Free choice in international corporate law: European and German corporate law in European competition between corporate law Systems". In An Economic Analysis of Private International Law, edited by Jürgen Basedow and Toshiyuki Kono, 187-205. Tübingen: Mohr Siebeck, 2006.

"Secured creditors in insolvency proceedings". In The Future of Secured Credit in Europe, edited by Horst Eidenmüller and Eva-Maria Kieninger, 273-283. Munique: De Gruyter Recht, 2008.

Eurohypothec Research Group. Response to the Green Paper on Mortgage Credit in the EU. 2005. http://ec.europa.eu/internal_market/finservices-retail/docs/home-loans/ comments/priv-es_eurohypothec-es.pdf.

European Commission. White Paper on the Integration of EU Mortgage Credit Markets - COM(2007)807 Final. Brussels, 2007. https://eur-lex.europa.eu/legal-content/EN/ TXT/?uri=celex\%3A52007DC0807

Fallon, Marc. "Groupe européen de droit international privé - Quatrième réunion, Barcelone, 29 septembre - 1er octobre 1994". Revue Belge de Droit International XXVII, no. 2 (1994): 717-721.

"Les conflits de lois et de juridictions dans un espace économique intégré L'expérience de la Communauté Européenne". Recueil des Cours de l'Académie de Droit International, 253 (1995): 9-282. 
Fallon, Marc, Kinsch, Patrick, and Kohler, Christian. "Le droit international privé européen en construction - Building European private international law”. In Vingt Ans de Travaux du GEDIP - Twenty Years' Work by GEDIP. Cambridge: Intersentia, 2011.

Fallon, Marc, and Meeusen, Johan. "Private international law in the European Union and the exception of mutual recognition". Yearbook of Private International Law 4 (2002): 37-66.

Eeckhout, Veerle van den. The Instrumentalisation of Private International Law: Quo Vadis? - Rethinking the 'Neutrality' of Private International Law in an Era of Globalisation and Europeanisation of Private International Law. Leiden: University of Leiden, 2012. http://ssrn.com/abstract=2338275.

Feraci, Ornella. “L'autonomia della volontà nel diritto internazionale privato dell'Unione Europea”. Rivista di Diritto Internazionale 96, no. 2 (2013): 424-491.

Fernandes, Pedro Pires. Da Euro-Hipoteca: Exposição da Proposta e Suas Características Principais. Dissertação de Mestrado apresentada à Faculdade de Direito da Universidade de Coimbra. Coimbra: (policopied), 2008.

Fernández Rozas, José Carlos, and Sánchez Lorenzo, Sixto. Curso de Derecho Internacional Privado. Madrid: Editorial Civitas, 1996.

Flessner, Axel. "Security interests in receivables - A European perspective". In The Future of Secured Credit in Europe, edited by Horst Eidenmüller and Eva-Maria Kieninger, 336-349. Munique: De Gruyter Recht, 2008.

Franzina, Pietro. "L’autonomia della volontà nel regolamento sui conflitti di leggi in materia di separazione e divorzio". Rivista di Diritto Internazionale XCIV, no. 2 (2011): 488-496.

Gannagé, Pierre. "La pénétration de l'autonomie de la volonté dans le droit international privé de la famille". Revue Critique de Droit International Privé 81, no. 3 (1992): 425-454.

Gardella, Anna. "Articulo 3. - Commentario al Regolamento (CE) n. 593/2008 del Parlamento europeo e del Consiglio del 17 giugno 2008 sulla legge applicabile alle obbligazioni contrattuali ('Roma I'): Francesco Salerno, Pietro Franzina (eds.)”. Le Nuove Leggi Civili Commentate no. 3/4 (2009): 611-629.

Le Garanzie Finanziarie nel Diritto Internazionale Privato. Milão: Giuffrè Editore, 2007.

Gaudemet-Tallon, Helène. "Comentário ao Acórdão da Cour de Cassation de 8 de Julho de 1969 (Société DIAC)”. La Semaine Juridique - Edition Générale II (1970): 16182.

“De nouvelles fonctions pour l'équivalence en droit international privé?". In $\mathrm{Le}$ Droit International Privé: Esprit et Méthodes, 303-325. Paris: Dalloz, 2005.

Gebauer, Martin. "Internationales Privatrecht und Warenverkehrsfreiheit in Europa". IPRax - Praxis des Internationalen Privat und Verfahrensrechts 15, no. 3 (1995): 152-156. 
Gerven, Walter van, and Wouters, Jan. "Free movement of financial services and the European Contracts Convention". In EC Financial Market Regulation and Company Law, edited by Mads Andenas and Stephen Kenyon-Slade, 43-79. Londres: Sweet \& Maxwell, 1993.

Gojon, Jean-François. "Loi réelle et loi de la créance dans le crédit hypothécaire: un concours encore incertain". In Mélanges en l'Honneur de Mariel Revillard - Liber Amicorum, 169-181. Paris: Defrénois, 2007.

Goldstein, Gerald, and Muir Watt, Horatia. "La méthode de la reconnaissance à lueur de la Convention de Munich du 5 septembre 2007 sur la reconnaissance des partenariats enregistrés". Journal du Droit International 137, no. 4 (2010): 1085-1125.

Gonçalves, Anabela de Sousa. Da Responsabilidade Extracontratual em Direito Internacional Privado. Coimbra: Almedina, 2013.

Gondra Romero, José Maria. "Integración económica e integración jurídica en el marco de la Comunidad Europea, desde una perspectiva sistemático-funcional”. In Tratado de Derecho Comunitario Europeo, edited by Eduardo García de Enterría, Julio González Campos and Santiago Muñoz Machado, 275-312. Madrid: Editorial Civitas, 1986.

González Campos, Julio. "Diversification, spécialisation, flexibilisation et matérialisation des règles de droit international privé". Recueil des Cours de l'Académie de Droit International 287 (2000): 9-426.

"El paradigma de la norma de conflicto multilateral". In Estudios Jurídicos en Homenaje al Profesor Aurelio Menéndez, 5239-5270. Madrid: Civitas, 1996.

"La Cour de Justice des Communautés Européennes et le non-droit international privé”. In Festschrift für Erik Jayme, 263-275. München: Sellier - European Law Publishers, 2004.

Goode, Roy. “A credit law for Europe”. International and Comparative Law Quarterly 23 (1974): 227-291.

"The Cape Town Convention on International Interests in Mobile Equipment".

In Towards a European Civil Code, edited by Arthur Hartkamp, Martijn Hesselink, Ewoud Hondius, Carla Joustra, Edgar du Perron and Muriel Veldman, 757-767. Haia: Kluwer Law International, 2004.

Gourio, Alain. "Le nouveau cadre juridique juridique du crédit aux particuliers en Europe”. Revue de Droit Bancaire et Financier 4, no. 2 (2003): 128-147.

Grünberger, Michael. "Alles obsolet? - Anerkennungsprinzip vs. klassisches IPR”. In Brauchen wir eine Rom 0-Verordnung?, edited by Stefan Leible and Hannes Unberath, 81-160. Jena: Jenaer Wissenschaftliche Verlagsgesellschaft, 2013.

Grundmann, Stefan. "Binnenmarktkollisionsrecht - vom klassischen IPR zur Integrationsordnung”. Rabels Zeitschrift für ausländisches und internationales Privatrecht 64, no. 3 (2000): 457-477. 
“The structure of European contract law". European Review of Private Law 9, no. 4 (2001): 505-528.

Guzmán Zapater, Mónica. “El principio del reconocimiento mutuo: ¿Un nuevo modelo para el derecho internacional privado comunitario?". Revista de Derecho Comunitario Europeo 3 (1998): 137-170.

"La ley nacional e intervención notarial en sucesiones". In Autonomía de la Voluntad en el Derecho Privado - Estudios en Conmemoración del 150 Aniversario de la Ley del Notariado, edited by Lorenzo Prats Albentosa, 303-357. Madrid: Consejo General del Notariado - Wolters Kluwer España, 2013.

"Un elemento federalizador para Europa: El reconocimiento mutuo en el ámbito del reconocimiento de decisiones judiciales". Revista de Derecho Comunitario Europeo 10 (2001): 405-438.

Hartkamp, Arthur. "Modernisation and harmonisation of contract law: Objectives, methods and scope". Uniform Law Review 8, no. 1/2 (2003): 81-89.

Hecke, Georges van. "Intégration économique et unification du droit privé". In De Conflictu Legum - Essays Presented to KOLLEWIJN and OFFERHAUS, 198-208. Leyden: A. W. Sijthoff, 1962.

Hein, Jan von. "Of older siblings and distant cousins: The contribution of the Rome II Regulation to the communitarisation of private international law". Rabels Zeitschrift für ausländisches und internationales Privatrecht 73, no. 3 (2009): 463-508.

Hein, Jan von, and Rühl, Giesela. "Towards a European code on private international law". In Cross-Border Activities in the EU - Making Life Easier for Citizens, edited by Directorate General for Internal Policies, 8-53. Bruxelas: European Parliament, 2015. Heuzé, Vincent. "De la compétence de la loi du pays d'origine en matière contractuelle ou l'anti-droit européen". In Le Droit International Privé: Esprit et Méthodes, 393-415. Paris: Dalloz, 2005.

Heymann, Jeremy. Le Droit International Privé à L'Épreuve du Fédéralisme Européen. Paris: Economica, 2010.

Jardim, Mónica. “A euro-hipoteca e os diversos sistemas registais europeus”. Boletim da Faculdade de Direito da Universidade de Coimbra LXXXV (2009): 743-763.

Jayme, Erik. "Identité culturelle et intégration: Le droit international privé postmoderne". Recueil des Cours de l'Académie de Droit International 251 (1995): 9-268.

"Il diritto internazionale privato nel sistema comunitario e i suoi recenti sviluppi normativi nei rapporti con Stati terzi". Rivista di Diritto Internazionale Privato e Processuale 2 (2006): 353-360.

"Party autonomy in international family and succession law: New tendencies". Yearbook of Private International Law 11 (2009): 1-10. 
Juenger, Friedrich K. "Private international law or international private Law?". King's College Law Journal 5 (1994-1995): 45-62.

Juvet, Isabelle. Des Sûretés Mobilières Conventionnelles en Droit International Privé. Berna: Peter Lang, 1991.

Khairallah, Georges. Les Sûretés Mobilières en Droit International Privé. Paris: Economica, 1984.

Kohler, Christian. "La Cour de Justice des Communautés Européennes et le droit international privé". Travaux du Comité Français de Droit International Privé (1993-1995): 71-87.

"La reconnaissance de situations juridiques dans l'Union européenne: le cas du nom patronymique". In La Reconnaissance des Situations en Droit International Privé, edited by Paul Lagarde, 67-83. Paris: Pedone, 2013.

Kronke, Herbert. "Connecting factors and internationality in conflict of laws and transnational commercial law". In Convergence and Divergence in Private International Law - Liber Amicorum Kurt Siehr, edited by Katharina Boele-Woelki, Talia Einhorn, Daniel Girsberger and Symeon Symeonides, 57-70. Zurique: Schulthess, 2010.

Lagarde, Paul. "Comentário ao Acórdão do Tribunal de Justiça de 5 de Novembro de 2002, Überseering, proc. C-208/00”. Revue Critique de Droit International Privé 92, no. 3 (2003): 508-536.

“Comentário ao Acórdão do Tribunal de Justiça de 14 de Outubro de 2008 Grunkin e Paul, proc. C-353/06”. Revue Critique de Droit International Privé 98, no. 1 (2009): 80-93.

"Développements futurs du droit international privé dans une Europe en voie d'unification: Quelques conjectures". Rabels Zeitschrift für ausländisches und internationales Privatrecht 68, no. 2 (2004): 225-243.

"La reconnaissance: mode d'emploi". In Vers de Nouveaux Équilibres entre Ordres Juridiques - Mélanges en L'Honneur de Helène Gaudemet-Tallon, 481-501. Paris: Dalloz, 2008.

"Les principes de base du nouveau règlement européen sur les successions". Revue Critique de Droit International Privé 101, no. 4 (2012): 691-732.

Lefranc, David. "La spécificité des règles de conflit de lois en droit communautaire dérivé (aspects de droit privé)". Revue Critique de Droit International Privé 94, no. 3 (2005): 413-446.

Leible, Stefan. "Parteiautonomie im IPR - Allgemeines Anknüpfungsprinzip oder Verlegenheitslösung?". In Festschrift für Erik Jayme, 485-503. München: Sellier European Law Publishers, 2004.

Leifeld, Janis. Das Anerkennungsprinzip im Kollisionsrechtssystem des internationalen Privatrechts. Tübingen: Mohr Siebeck, 2010. 
Leitão, Luís Menezes. Garantias das Obrigações. Coimbra: Almedina, 2012.

London Economics. The Costs and Benefits of Integration of EU Mortgage Markets Report for European Commission, DG-Internal Market and Services. London, 2005.

Low, Simon, Sebag-Montefiore, Matthew, and Dübel, Achim. Study on the Financial Integration of European Mortgage Markets. London: Mercer Oliver Wyman European Mortgage Federation, 2003.

Luckow, Andreas. "Charts on business structures". In Basic Guidelines for a Eurohypothec

- Outcome of the Eurohypothec Workshop November 2004/April 2005, edited by Agnieszka Drewics-Tulodzieca, 24-38. Warsaw: Mortgage Credit Foundation, 2005.

Luzzatto, Riccardo. "Riflessioni sulla C. D. Comunitarizzazione del Diritto Internazionale Privato". In Nuovi Strumenti del Diritto Internazionale Privato - Liber Fausto Pocar, edited by Gabriella Venturini and Stefania Bariatti, 613-625. Milano: Giuffrè Editore, 2009.

Mankowski, Peter. "Binnenmarkt-IPR - Eine Problemskizze". In Aufbrucht nach Europa: 75 Jahre Max-Planck-Institut für Privatrecht, edited by Jürgen Basedow, Ulrich Drobnig, Reinhard Ellger, Klaus Hopt, Hein Kötz, Rainer Kulms and ErnstJoachim Mestmäcker, 595-615. Tübingen: Mohr Siebeck, 2001.

Mansel, Heinz-Peter. “Anerkennung als Grundprinzip des Europäischen Rechtsraums”. Rabels Zeitschrift für ausländisches und internationales Privatrecht 70, no. 4 (2006): 651-731.

"Parteiautonomie, Rechtsgeschäftslehre der Rechtswahl und allgemeinen Teil des europäischen Kollisionsrechts". In Brauchen wir eine Rom 0-Verordnung?, edited by Stefan Leible and Hannes Unberath, 241-292. Jena: Jenaer Wissenschaftliche Verlagsgesellschaft, 2013.

Matias, Armindo Saraiva. "Obrigações hipotecárias e titularização de créditos hipotecários". Boletim da Faculdade de Direito da Universidade de Coimbra LXXXV (2009): 621-637.

Mattera, Alfonso. "L'élimination des barrières techniques et la mise en oeuvre de la reconnaissance mutuelle”. Revue du Marché Commun 334 (1990): 80-92.

Mayer, Pierre, and Heuzé, Vincent. Droit International Privé. Paris: Montchrestien, 2010.

Meeusen, Johan. "Instrumentalisation of private international law in the European Union: towards a European conflicts revolution?". European Journal of Migration and Law 9, no. 3 (2007): 287-305.

Miaja de la Muela, Adolfo. "Las normas materiales de Derecho internacional privado". Revista Española de Derecho Internacional XVI, no. 3 (1963): 425-457.

Michaels, Ralf. "EU law as private international Law? Maastricht the country-of-origin principle as vested-rights theory". Journal of Private International Law 2, no. 2 (2006): 195-242. 
“The new European choice-of-law revolution". Tulane Law Review 82, no. 5 (2008): 1607-1644.

Miguel Asensio, Pedro. "Integración europea y derecho internacional privado". Revista de Derecho Comunitario Europeo 1, no. 2 (1997): 413-445.

Mills, Alex. Towards a Public International Perspective on Private International Law: Variable Geometry and Peer Governance. 2012. http://ssrn.com/abstract=2025616.

Muir Watt, Horatia. "Aspects économiques du droit international privé”. Recueil des Cours de l'Académie de Droit International 307 (2004): 25-383.

"L'entrave à la prestation transfrontière de services: Réflexions sur l'impact des libertés économiques sur le droit international privé des États membres". In Études Offertes à Jacques Béguin - Droit et Actualité, 545-565. Paris: LITEC, 2005.

"The challenge of market integration for European conflicts theory". In Towards a European Civil Code, edited by Arthur Hartkamp, Martijn Hesselink, Ewoud Hondius, Carla Joustra, Edgar du Perron and Muriel Veldman, 191-204. Haia: Kluwer Law International, 2004.

Muñiz Espada, Esther. Bases para una Propuesta de Eurohipoteca. Valencia: Ed. Tirant lo Blanch, 2005.

Nasarre Aznar, Sergio. "The Eurohypothec: A common mortgage for Europe". The Conveyancer and the Property Lawyer (2005): 32-52.

Niboyet, J.-P. "Le Code Civil en préparation et les règles de solution des conflits de lois". Travaux du Comité Français de Droit International Privé Anné 7 (1945-1946): 13-52.

Nuyts, Arnaud. "L'application des lois de police dans l'espace (Réflexions au départ du droit belge de la distribution commerciale et du droit communautaire)". Revue Critique de Droit International Privé 88 (1999): 31-74 and 245-265.

"Le droit de rétention en droit international privé: Quelques observations sur le rôle de la loi de l'obligation, de la loi réelle, et de la loi du lieu d'exécution”. Revue Générale de Droit Civil Belge 6, no. 1 (1992): 30-54.

Ortino, Matteo. "The role and functioning of mutual recognition in the European market of financial services". International and Comparative Law Quarterly 56, no. 2 (2007): 309-338.

Ortiz Vidal, María Dolores. "El caso Grunkin-Paul: Notas a la STJUE de 14 de octubre de 2008". Cuadernos de Derecho Transnacional 1, no. 1 (2009): 143-151.

"Espacio judicial europeo y Tratado de Lisboa: Hacia un nuevo derecho internacional privado". Cuadernos de Derecho Transnacional 2, no. 1 (2010): 376-402.

Padesca, Ana Luísa Balmori. "Elección de ley y estatuto personal”. In Autonomía de la Voluntad en el Derecho Privado - Estudios en Conmemoración del 150 Aniversario de la Ley del Notariado, edited by Lorenzo Prats Albentosa, 359-388. Madrid: Consejo General del Notariado - Wolters Kluwer España, 2013. 
Paredes Pérez, José Ignacio. “Alcance y contenido de la noción de equivalencia en el derecho internacional privado". Anuario Español de Derecho Internacional Privado XII (2012): 91-126.

Paschalidis, Paschalis. Freedom of Establishment and Private International Law for Corporations. Oxford: Oxford University Press, 2012.

Patrão, Afonso. Autonomia Conflitual na Hipoteca e Reforço da Cooperação Internacional: Removendo Obstáculos ao Mercado Europeu de Garantias Imobiliárias. Lisboa: Livros Horizonte, 2017.

Pfeiffer, Thomas. "Der Stand des internationalen Sachenrechts nach seiner Kodification". IPRax - Praxis des Internationalen Privat und Verfahrensrechts 20 (2000): 270-281.

Pinheiro, Luís de Lima. "Concorrência entre sistemas jurídicos na União Europeia e direito internacional privado”. O Direito II (2007): 255-281.

"Direito aplicável às operações bancárias internacionais". In Estudos de Direito Internacional Privado, 233-282. Coimbra: Almedina, 2009.

"Direito Internacional Privado". In Introdução e Direito de Conflitos - Parte Geral. Coimbra: Almedina, 2014.

"O direito de conflitos e as liberdades comunitárias de estabelecimento e de prestação de serviços". In Seminário Internacional sobre a Comunitarização do Direito Internacional Privado - Direito de Conflitos, Competência Internacional e Reconhecimento de Sentenças Estrangeiras, edited by Luís de Lima Pinheiro, 79-109. Coimbra: Almedina, 2005.

Pissarra, Nuno Andrade. "Normas de aplicação imediata e direito comunitário". In Normas de Aplicação Imediata, Ordem Pública Internacional e Direito Comunitário, 9-140. Coimbra: Almedina, 2004.

Ploeger, Hendrik, and van Loenen, Bastiaan. Response to the Green Paper on Mortgage Credit in the EU. Delft, 2005. http://ec.europa.eu/internal_market/finservices-retail/ docs/home-loans/comments/priv-nl_ploeger_vanloenen-en.pdf.

Poillot-Peruzzetto, Sylvaine. "Comentário ao Acórdão do Tribunal de Justiça de 2 de Outubro de 2003, Garcia Avello, proc. C-148/02". Journal du Droit International 131, no. 4 (2004): 1219-1237.

Ramaekers, Eveline. European Union Property Law - From Fragments to a System. Cambridge - Antwerp: Intersentia, 2013.

Ramos, Rui Moura. "A evolução recente do direito internacional privado da família". In Direito da Família e Direito dos Menores: Que Direitos no Século XXI?, edited by Maria Eduarda Azevedo and Ana Sofia Gomes, 67-82. Lisboa: Universidade Lusíada Editora, 2014.

"La protection de la partie contractuelle la plus faible en droit international privé portugais". In Das Relações Privadas Internacionais - Estudos de Direito Internacional Privado, 197-241. Coimbra: Coimbra Editora, 1995. 
"O Tribunal de Justiça das Comunidades Europeias e a teoria geral do direito internacional privado. Desenvolvimentos recentes”. In Estudos de Direito Internacional Privado e de Direito Processual Civil Internacional, 39-58. Coimbra: Coimbra Editora, 2007.

Reich, Norbert. "Competition between legal orders: A new paradigm of EC law?". Common Market Law Review 29, no. 5 (1992): 861-896.

Remien, Oliver. "European private international law, the European Community and its emerging area of freedom, security and justice”. Common Market Law Review 38, no. 1 (2001): 53-86.

Requejo Isidro, Marta. "Libertades comunitarias y registro civil: Algunos casos de incidencia mutua y pautas de solución". In Derecho Registral Internacional - Homenaje a la Memoria del Profesor Rafael Arroyo Monteiro, edited by Pedro Miguel Asensio, 95-107. Madrid: Iprolex, 2003.

Ribeiro, Geraldo. “A europeização do direito internacional privado e direito processual internacional: Algumas notas sobre o problema da interpretação do âmbito objectivo dos regulamentos comunitários". Julgar, no. 23 (2014): 263-293.

Rigaux, François. "Les situations juridiques individuelles dans un système de relativité générale - Cours général de droit international privé". Recueil des Cours de l'Académie de Droit International 213 (1989): 9-407.

Rigaux, François, and Fallon, Marc. Droit International Privé. Bruxelas: De Boeck \& Larcier, 2005.

Rocío Diéguez, Oliva. La Eurohipoteca: Luces y Sombras de la Pretendida Unificación en Materia Hipotecaria. Berkeley: eScholarship, 2009. http://escholarship.org/uc/ item/2s48r5vn.

Rodríguez Benot, Andrés. "El criterio de conexión para determinar la ley personal: Un renovado debate en derecho internacional privado". Cuadernos de Derecho Transnacional 2, no. 1 (2010): 186-202.

Rodríguez Benot, Andrés, and Ybarra Bores, Alfonso. "La armonización del crédito hipotecario en la Unión Europea”. Revista Analuza de Derecho del Turismo 5 (2011): 115-145.

Roth, Wulf-Henning. "Der Einfluß des Europäischen Gemeinschaftsrechts auf das internationale Privatrecht". Rabels Zeitschrift für ausländisches und internationales Privatrecht 55, no. 4 (1990): 623-673.

"Die Freiheiten des EG-Vertrages und das nationale Privatrecht". Zeitschrift fur Europäisches Privatrecht 1 (1994): 5-33.

"Secured credit and the internal market: The fundamental freedoms and the EU's mandate for legislation". In The Future of Secured Credit in Europe, edited by 
Horst Eidenmüller and Eva-Maria Kieninger, 36-67. München: De Gruyter Recht, 2008.

Röthel, Anne. “Internationales Sachenrecht im Binnenmarkt”. Juristen Zeitung (JZ) 58, no. 21 (2003): 1027-1035.

Sánchez Jordán, Elena. “Garantías sobre bienes inmuebles: La Eurohipoteca”. In Derecho Privado Europeo, edited by Sergio Cámara Lapuente, 987-1007. Madrid: Editorial Colex, 2003.

Santos, António Marques dos. "Direito aplicável aos contratos celebrados através da internet e tribunal competente". In Estudos de Direito Internacional Privado e de Direito Público, 159-225. Coimbra: Almedina, 2004.

Schäfer, Hans-Bernd, and Lantermann, Katrin. "Choice of law from an economic perspective". In An Economic Analysis of Private International Law, edited by Jürgen Basedow and Toshiyuki Kono, 87-119. Tübingen: Mohr Siebeck, 2006.

Scherber, Nina. Europäische Grundpfandrechte in der nationalen und internationalen Insolvenz im Rechtsvergleich. Frankfurt am Main: Peter Lang, 2004.

Schmid, Christoph. "Options under EU Law for the implementation of a Eurohypothec". In Basic Guidelines for a Eurohypothec - Outcome of Eurohypothec Workshop November 2004/April 2005, edited by Agnieszka Drewics-Tulodzieca, 61-68. Warsaw: Mortgage Credit Foundation, 2005.

Segré, Claudio. The Development of a European Capital Market. Bruxelas: Comissão Europeia, 1966. http://aei.pitt.edu/31823/1/Dev_Eur_Cap_Mkt_1966.pdf.

Servais, Dominique. "Intégration des marchés financiers". In Commentaire J. Mégret. Brussels: Éditions de l’Université de Bruxelles - Institut d'Études Européennes, 2007. Silva, Nuno Ascensão. "Do estatuto pessoal - Unidade e dispersão (algumas notas a propósito da comemoração dos 35 anos do Código Civil”. In Comemorações dos 35 anos do Código Civil e dos 25 Anos da Reforma de 1977, 549-649. Coimbra: Coimbra Editora - Faculdade de Direito da Universidade de Coimbra, 2006.

Smulders, Ben, and Glazener, Paul. "Harmonization in the field of insurance law through the introduction of community rules of conflict". Common Market Law Review 29, no. 4 (1992): 775-797.

Soares, Maria Ângela Bento. "A liberdade de estabelecimento das sociedades na União Europeia”. Temas de Integração 15-16 (2003): 283-321.

"O Acórdão Inspire Art Ltd: Novo incentivo jurisprudencial à mobilidade das sociedades na União Europeia”. Temas de Integração 17 (2004): 123-159.

Sonnenberger, Hans Jürgen. "Europarecht und internationales Privatrecht”. Zeitschrift für vergleichende Rechtswissenschaft: Archiv für internationales Wirtschaftsrecht 1 (1996): 3-47. 
Sousa, António Frada de. A Europeização do Direito Internacional Privado. Porto: (policopied), 2012.

Stoll, Hans. "Rechtskollisionen beim Gebietswechsel beweglicher Sachen". Rabels Zeitschrift für ausländisches und internationales Privatrecht 38 (1974): 450-467.

"Zur gesetzlichen Regelung des internationalen Sachenrechts in Art. 43-46 EGBGB". IPRax - Praxis des Internationalen Privat und Verfahrensrechts 4 (2000): 259-270.

Tebbens, Harry Duintjer. "Les conflits de lois en matière de publicité déloyale à l'épreuve du droit communautaire”. Revue Critique de Droit International Privé 83, no. 3 (1994): 451-481.

"Private international law and the Single European Market: Coexistence or cohabitation". In Forty Years On: The Evolution of Postwar Private International Law in Europe, 49-69. Daventer: Kluwer - University of Amsterdam, 1990.

Tison, Michel. "Unravelling the general good exception: The case of financial services". In Services and Free Movement in EU Law, edited by Mads Andenas and WulfHenning Roth, 321-381. Oxford: Oxford University Press, 2002.

Torga, Maarja. "Party autonomy of the spouses under the Rome III Regulation in Estonia - Can private international law change substantive law?". Nederlands Internationaal Privaatrecht 4 (2012): 547-554.

Vaquer Aloy, Antoni. “¿Armonización del derecho privado en Europa vs. codificación der derecho civil en Cataluña?". In Estudios Jurídicos en Homenaje al Profesor Luis Díez-Picazo, edited by Antonio Cabanillas Sánchez, 1055-1072. Madrid: Civitas Thomson, 2003.

Vareilles-Sommières, Pascal de. "La communautarisation du droit international privé des contrats: Remarques en marge de l'uniformisation européenne du droit des contrats”. In Le Droit International Privé: Esprit et Méthodes, 781-801. Paris: Dalloz, 2005.

Verhagen, Hendrik, and van Dongen, Sanne. "Cross-border assignments under Rome I". Journal of Private International Law 6, no. 1 (2010): 1-21.

Vicente, Dário Moura. A Tutela Internacional da Propriedade Intelectual. Coimbra: Almedina, 2008.

"Liberdades comunitárias e direito internacional privado". Revista da Ordem dos Advogados Ano 69 (2009): 729-813.

"Perspectivas da harmonização e unificação internacional do direito privado numa época de globalização da economia". In Estudos em Honra do Professor Doutor José de Oliveira Ascensão, edited by António Menezes Cordeiro, Pedro Pais de Vasconcelos and Paula Costa e Silva, 1655-1680. Coimbra: Almedina, 2008.

"Um código civil para a Europa? Algumas reflexões". In Direito Internacional Privado - Ensaios, 7-33. Coimbra: Almedina, 2002. 
Vignes, Daniel. "Le rapprochement des législations". In Commentaire J. Mégret - Le Droit de la CEE - 5 - Dispositions Fiscales. Rapprochement des Législations, 299-379: Éditions de l’Université de Bruxelles - Institut d'Études Européennes, 1993.

"Remarques sur la double nature de la reconnaissance mutuelle". In Hacia un Nuevo Orden Internacional y Europeo - Estudios en Homenaje al Profesor Don Manuel Díez de Velasco, edited by Manuel Pérez Gonzáles, Luis Ignacio Sánchez Rodríguez, José Carlos Fernandez Rozas, Oriol Casanovas y la Rosa, Victoria Abellán Honrubia and Gil Carlos Rodríguez Iglesias, 1293-1296. Madrid: Tecnos, 1993.

Wachter, Thomas. "Die Eurohypothek - Grenzüberschreitende Kreditsicherung an Grundstücken im Europäischen Binnenmarkt”. Zeitschrift für Wirtschafts- und Bankrecht (WM - Wertpapier Mitteilungen) 53, no. 2 (1999): 49-70.

"La garantie de crédit transfrontalier sur les immeubles au sein de l'Union Européenne - L'Eurohypothèque”. Notarius International 4, no. 4 (1999): 174-188.

Watt, Gary. "The Eurohypothec and the English mortgage". Maastricht Journal of European and Comparative Law 13, no. 2 (2006): 173-193.

Weber, Rolf. "Parteiautonomie im internationalen Sachenrecht?". Rabels Zeitschrift für ausländisches und internationales Privatrecht 44 (1980): 510-530.

Wendehorst, Christiane. "Sachenrecht”. In Münchener Kommentar zum bürgerlichen Gesetzbuch, edited by Roland Rixecker and Franz Jürgen Säcker, 217-373. München: Beck, 2010.

Wilderspin, Michael, and Lewis, Xavier. "Les relations entre le droit communautaire et les règles de conflits de lois des États membres". Revue Critique de Droit International Privé 91, no. 1 (2002): 1-37.

Wilmowsky, Peter von. "EG-Vertrag und kollisionsrechtliche Rechtswahlfreiheit". Rabels Zeitschrift für ausländisches und internationales Privatrecht 62, no. 1 (1998): $1-37$. 